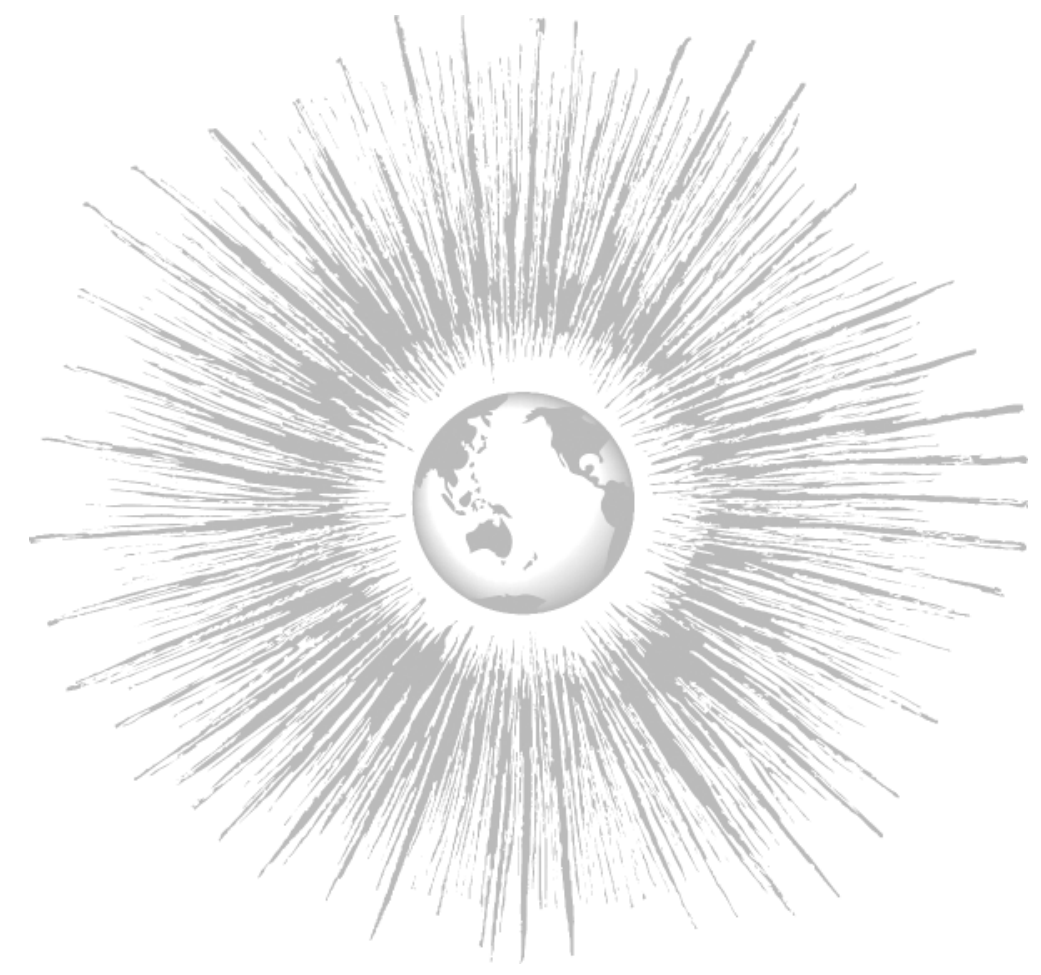

ABSTRACT:

This review covers a range of measures and methods frequently employed in the empirical analysis of global income inequality and global income distribution. Different determinan factors along with the quantification of their impacts and empirical results from differen case studies are presented. A number of issues crucial to the study of global income inequality are also addressed. These are the concepts, measurement and decomposition of inequality the world distribution of income and inequality measured at different levels of aggregation:

\section{The World Distribution of Income and Income Inequality: A Review of the Economics LiterATURE*}

Almas Heshmati

\section{INTRODUCTION}

Tnequality can have many dimensions. Economists are concerned specifically with the monetarily measurable dimension related to individual or household incomes. However, this is just one perspective and inequality is also linked to inequality in skills, education, opportunities, happiness, health, life expectancy, welfare, assets and social mobility. ${ }^{1}$ Here income inequality refers to the inequality of the distribution of individuals, households or some per capita measure of income. The Lorenz Curve is the standard approach used for analyzing the size distribution of income and measures of inequality and poverty. It plots the cumulative share of total income against the cumulative proportion of income receiving units. The divergence of a Lorenz curve for a given income distribution from the line of perfect equality is measured by some index of inequality. The most widely used index of inequality is the Gini coefficient. Among the other measures of inequality are the range, variance, squared coefficient of variation, variance of log incomes, absolute and relative mean deviations, and Theil's two

\author{
Almas Heshmati \\ University of Kurdistan-Hawler \\ and Techno-Economics \& Policy Program \\ College of Engineering, Seoul National University \\ San 56-1, Shinlim-dong, Kwanak-gu \\ Seoul 151-742 South Korea \\ heshmati@snu.ac.kr
}

* Comments and suggestions from Amit Kumar Bhandari, Farideh Ramjerdi, an anonymous referee and the Managing Editor of JWSR, Kenneth Barr are gratefully acknowledged.

1. Heshmati (2004a) reviews recent advances in the measurement of inequality and gives attention to the interrelationship between income and non-income dimensions of inequality.

JOURNAL OF WORLD-SYSTEMS RESEARCH, XII, I, JULY 2006, 6I-IO7

bttp://jwsr.ucr.edu/

ISSN $1076-156 \mathrm{X}$

(C) 2006 Almas Heshmati 
inequality indices. There are three basic properties that one would expect the above indices to satisfy: mean or scale independence, population size independence and the Pigou-Dalton condition. The Gini coefficient, squared coefficient of variation and Theil's two measures satisfy each of these properties (see Anand I997) ${ }^{2}$

The literature on economic inequality is growing as a result of increasing interest in measuring and understanding the level, causes and development of income inequality and poverty. In the I99os there was a shift in research, from one previously concerned with economic growth, the identification of the determinants of economic growth and the convergence in per capita incomes across countries, to one focused on the analysis of the distribution of income, its development over time and the identification of factors determining the distribution of income and the reduction of poverty. ${ }^{3}$ This shift is among other things a reflection of the changes in technology and an increased awareness of the growing disparity and importance of income redistribution and poverty reductions. The growing disparity calls for the analysis of various aspects of income inequality and poverty including their measurement, decomposition, causal factors, as well as issues of inequality reduction, poverty elimination and policies geared toward income redistribution. ${ }^{4}$

The extensive literature emerging in recent years has focused on the study of how the distribution of incomes across countries and globally has developed over time. Two empirical regularities identified in the distribution of income are the tendency for income per capita to converge, and an increase in inequality in the distribution of personal income in many countries. The increased interest in the study of income inequality may be both cause and effect of the availability of

2. For reviews of inequality see Subramanian (1997), Cowell (2000) and Heshmati (2004a).

3. For a selection of studies of growth and convergence in per capita incomes see Barro (I99I), Barro and Sala-i-Martin (I995), Islam (I995), Mankiew, Romer and Weil (I992), and Quah (1996). Quah (2002), Ravallion (2003), and Sala-i-Martin (2002a) analyze convergence in income inequality, while Acemoglu and Ventura (2002), Atkinson (1997), Bourguignon and Morrisson (2002), Gottschalk and Smeeding (1997) and Milanovic (2002a) focus on the distribution of income. Acemoglu (2002), Caminada and Goudswaard (200I), Cornia and Kiiski (200I), Gotthschalk and Smeeding (2000), Milanovic (2002a), O'Rourke (200I), Park (200I), Sala-i-Martin (2002b) and Schultz (I998) examine trends in income inequality. The relationship between inequality, poverty and growth is reviewed in Heshmati (2004c).

4. For a recent review of the decomposition of income inequality and poverty see Heshmati (2004b). income distribution data. Availability of household surveys has been improved and several standardized databases have also been created. These allow for the analysis of income distribution at the most disaggregate individual or per capita household levels. Income distribution is otherwise often analyzed at three levels of aggregation, namely global, international and intra-national. ${ }^{5}$ It can also be measured at the continental and sub-continental levels where one can examine inequality both between and within economic or geographic regions. There is evidence that poverty and inequality have developed differently between and within regions. ${ }^{6}$

There are two empirical regularities in the distribution of income: the tendency for income per capita to converge (decrease in inequality), and the increase in inequality in the distribution of personal income in various countries (Schultz 1998). Inequality increased in Western countries in the 1980s and in transition countries in the ig9os. The reasons for increased interest in income inequality are the theoretical development and availability of data on income distribution (Milanovic 2002a). The theoretical reasons are the better incorporation of inequality in economic theory, the growth-inequality relationship and the link between inequality and political economy. Availability of household surveys has improved in the former Soviet Union, Eastern Europe and Africa. Several standardized databases have been created, often based on the experiences gained from the Luxembourg Income Study (LIS), and now include the Household Expenditure and Income Data for Transition Economies (HEIDE), Africa Poverty Monitoring (APM), and the World Bank's Living Standards Measurement Study Household Surveys (LSMS). In several studies, based on these databases, inequality and poverty are related to a number of determinant factors. Due to the availability of data, the empirical results are mainly based on the second half of the twentieth century. We aim to cover a range of measures

5. Global or world income inequality refers to inequality differences between all individuals in the world (Milanovic 2002a; Schultz 1998; Quah 1999; Bourguignon and Morrisson 2002; Sala-i-Martin 2002a), while international income inequality refers to the economic disparity between countries (Acemoglu 2002; Cornia and Kiiski 200I; Gothscalk and Smeeding 1997; and Milanovic 200I). At the intra-national level inequality refers to the distribution of income among people within individual countries (Cameron 2000; Cowell, Ferreira and Lichtfield 1998; Gustafsson and Shi 2002; and Liebbrandt, Woolard and Woolard 2000). Several of these studies cover two or all three dimensions.

6. Continental and regional inequalities are discussed in Heshmati (2004d) and (2004e) respectively. 
and methods frequently employed in the empirical analysis of global income inequality and income distribution. Different determinant factors along with the quantification of their impacts together with empirical results from different case studies are presented. These results are further contrasted to those based on the World Income Inequality Database (WIID) covering almost the same period and the same group of countries.

This review addresses a number of issues crucial to studies of global income inequality. These are the concepts, measurement and decomposition of inequality, the world distribution of income and inequality measured at different levels of aggregation: global, international and intra-national. In this study we analyze income at each of these levels, and discuss the benefits and limitations of each approach and present empirical results found in the literature, including those based on the World Income Inequality Database (WIID). Research on world income inequality contributes to the increased awareness of the problem, its measurement and quantification, the identification of causal factors and policy measures that affect global inequality. Since several studies cover more than one dimension or aggregate level of inequality, there is some degree of overlapping in the three subsections of this study, the global, international and intra-national.

It should be noted that this article is limited to a review of the literature on income inequality in the discipline of economics, and as such does not cover the other social sciences, namely sociology and political science. These literatures to a great extent overlap. A number of sociological literature reviews have been published on the issue of world income inequality and its development. Firebaugh and Goesling (2004), Firebaugh (1999 and 2000a) and Babones and Turner (2003) are among the major sociological review articles that have been published in recent years. Similar reviews for readers who are interested in the political science literature on inequality are available in the series of edited volumes by Seligson and Passe-Smith (2003). Sociological research on the empirics of world income inequality have resulted in the now famous debate between Korzeniewicz and Moran (2000) and Firebaugh (200ob). The debate is related to the weighting procedures for assessing trends in world income inequalities. The debate centers around the reliance on the use of exchange-rate per capita incomes or purchasing power parity-based incomes in measuring world income inequality and its decomposition into between- and within-country components. Such debate on the premise and pitfalls in the use of secondary datasets and weighting procedures exists among economists as well (Atkinson and Brandolini 200I). ${ }^{7}$

7. There are also two special issues on global income inequality published in the Journal of World-Systems Research (Babones 2002; Bata and Bergesen 2002a, 200ob; Bergesen and Bata 2002; and Bornschier 2002).
The rest of the paper is organised as follows. In the second section we review alternative approaches examining the distribution of income among representative world individuals and present some critiques of these approaches. In the third section we look at between-country inequality and factors affecting the international level and its development over time. The findings of the trend are compared with those based on the WIID database. In the fourth section intranational inequality is addressed. The fifth section explores factors affecting the shape of the world distribution of income. These factors include trade, education, growth, redistribution policies and globalization. The sixth and final section discusses the redistribution of world income and offers a post-script and conclusion to the review.

\section{THE DISTRIBUTION OF INCOME AMONG THE WORLD INDIVIDUALS}

An analysis of the dynamics of the distribution of income across people worldwide would ideally be based on data on individual incomes accruing over time. One could then estimate the entire income distribution across individuals and characterize its dynamics through time. Such data representative of populations, consistent over time and across countries are not available and are very unlikely to be produced globally anytime soon. Similar data but on a smaller scale for the OECD and transition countries, the LIS and the HEIDE are available. There are, however, major differences in defining various pre- and post-tax income components and transfers by countries and over time.

Despite the above problems, the LIS could serve as an example in the creation of a World Income Study (WIS) database. Ideally this database would allow for the testing of alternative distributional hypotheses, the use of a variety of concepts and measurements and the uncovering of different characteristics of income inequality.

In the absence of a WIS database or other appropriate databases, several researchers have attempted to develop alternative empirical frameworks based on aggregative statistics of the underlying data to serve in different ways as a substitute in the analysis of global income distribution and income inequality. ${ }^{8}$

\section{Alternative Approaches to the Analysis of the World Distribution of Income}

There are a number of ways to estimate income distribution and global income inequality and to construct world indices of income distribution. One

8. A brief description of these data sets together with the outcomes is given in Heshmati (2004f). 
procedure is to use national household income (or expenditure) survey data collected mainly since the mid-I980s in providing direct income information by quintiles and deciles for individual countries to construct world income distribution over time (Milanovic 2002a). The use of short, unequal and unbalanced time periods is among the limitations of this approach.

A second approach is to use the mean income or GDP per capita income for individual countries complemented by the Gini coefficient or standard deviation as the measurement of income dispersion within each country and make an assumption of log-normality in constructing income distribution for each (Schultz 1998; and Quah 1999).

A third approximation is to use the known income distribution of representative countries and apply this to other countries with geographical and economic similarities but with missing data (Bourguignon and Morrisson 2002). Among the limitations of this approach are variations in intertemporal patterns of income distribution.

A fourth way is to use aggregate GDP data and within-country income shares to assign a level of income to each person in the world to estimate income distribution and global income inequality using different indices (Berry, Bourguignon and Morrrisson 1983; and Sala-i-Martin 2002b). The second and fourth alternatives are similar in their use of per capita GDP but differ in providing additional information on within-country income shares used.

The fifth, and a rather simple approach, is to divide the global population into percentiles in terms of per capita income. In this approach, introduced by Park (200I), global income inequality refers to inequality within the global population. This method is similar to the second approach. Recently Dikhanov and Ward (2002) combined micro and macro approaches to reconstruct the world's income distribution.

It is to be noted that despite the limited number of time points the first alternative with direct income information at the individual (or household) level is the preferred approach. It allows for the analysis and comparison of inequality and distribution by subgroups, sectors, locations and household attributes across countries. Below we briefly describe each alternative in estimating world income distribution.

\section{Studies of the World Distribution of Income}

\section{A. Milanovic's Approach}

World income or expenditure distribution based on the first approach at the individual level was derived by Milanovic (2002a). ${ }^{9}$ This study is based on household surveys from 9I countries for 1988 and $1993{ }^{10}$ Income and expenditure are adjusted for purchasing power parity (PPP) between countries. Inequality measured by the Gini coefficient increased from 0.63 in 1988 to 0.66 in 1993. This change holds up regardless of changes in the sample countries, PPP adjustments and inequality measurements (Gini coefficient and Theil). Inequality for each of the five regions (Africa; Asia; Latin America; Eastern Europe and the FSU; and Western Europe, North America and Oceania) is decomposed. Using the Pyatt (1976) type decomposition, overall inequality is decomposed into within-country $(W)$, between-country $(B)$ and overlapping $(L)$ components. The decomposition formula for the Gini coefficient is:

$$
\text { Gini }=W_{i}+B_{i}+L_{i}=\sum_{i=1}^{n} \operatorname{Gini}_{i} p_{i} \pi_{i}+\frac{1}{\mu} \sum_{i=1}^{n} \sum_{j>i}^{n}\left(y_{j}-y_{i}\right) p_{i} p_{j}+L_{i}
$$

where $y_{i}$ is the mean income of country $i$, Gini $i_{i}$ the Gini coefficient for country $i$, $\pi_{i}$ the income share of the total income in the region, $p_{i}$ the population share of country $i$ and $\mu$ the mean income of the region. Results show that the increase was driven by between-country rather than within-country differences in mean income. The main reason for low within-country inequality is the low and crowded per capita mean income. Results based on only two years of observation might be sensitive to different developments of business cycles in major countries or non-random (outlier) year differences. Furthermore, the uneven survey quality and differences in survey definitions of income and expenditure are two potential problems. The assumption of equality of individuals within each decile, the problem of mixing income and expenditure, and the use of a single and PPP exchange rate may bias overall inequality and its decomposition. Milanovic aims to establish the benchmark for world inequality in 1988 and 1993.

\section{B. Schultz and Quah's Approach}

In analyzing inequality in the distribution of personal income in the world Schultz (1998) uses four different types of data: population estimates, PPP prices-adjusted GDP per capita incomes, national estimates of the size distribution of household incomes, and intra-household gender differences in education

9. This paper is methodologically similar to those by Ravallion, Datt and van der Walle (I99I) and Chen, Datt and Ravallion (1994). These are also based on household surveys, but limited to developing countries and focus on changes in world poverty, not on inequality.

10. In addition to the common sample (9I), a number of countries are observed only in 1988 (IO) and only in 1993 (28), or not included in either year (6I). The common sample is extended by Milanovic (200I) to I 26 countries. 
inequality. Three indicators of income inequality are computed. The variance of the logarithm of income, Gini concentration ratio, and Theil mean log-deviation are estimated based on the cumulative shares of income received by the quintile shares of income units. The variance in the logarithms of per capita GDP in PPP prices increased in the world from 1960 to 1968 and has decreased since the midI970s. In the latter period the convergence in inter-country incomes offsets any increase in within-country income inequality. The variance measure is decomposed into between-country, within-country and within-household log income variance components. About two-thirds of overall inequality is due to intercountry and one-third to intra-country components. Inter-household inequality and gender differences in education are the main contributors to within-country inequality. The results are sensitive to changes in sample size and the quality of the data underlying the inter-household component. For instance, if China is included in the sample the decline in world inequality after 1975 is no longer evident.

In another study using an approach similar to Schultz's (1998), Quah (1999) combines distribution dynamics for per capita incomes across countries with personal income distributions within countries over time. The result is expected to produce a picture of worldwide income distribution dynamics across people. Given that information on actual distributions for economies in a number of periods are available, worldwide income distribution is obtained using country and world population sizes. The results based on country data for $1980-92$ show that macroeconomic factors determine cross-country patterns of growth and convergence in growth determines world inequalities. However, the relation between a country's growth and its within-country inequality plays a small role in global inequality dynamics. The positive effects of economic growth on individual incomes and reductions in poverty overwhelm any potential negative impacts like increases in inequality. The increase in inequality between 1980 and 1992 is due entirely to between-country inequality and is derived from macroeconomic growth, not from microeconomic changes in within-country inequalities. Some numbers on inequality and changes in levels of poverty in India and China during the period $1980-92$ are presented without much detail concerning the kinds of data used and methods employed. The advantage here is the sequence of annual observations for individual countries. However, Quah's manuscript is incomplete and results are far from final.

\section{Bourguignon and Morrisson's Approach}

Bourguignon and Morrisson (2002) attempt to estimate world inequality of personal income and its evolution over time since 1820 . Since data covering such a long period are only sparsely available, the countries are divided into 33 groups of single and multiple countries. The groups of countries are in turn aggregated into 6 blocks defined on a geographical, economic or historical basis. From the early nineteenth century to the eve of the First World War, the Gini coefficient increased from 0.50 to 0.61 . After a deceleration period between the two world wars, it increased to 0.64 in 1950 . It had, however, stabilized during the latter half of the twentieth century. The increase in the Gini coefficient was 30 percent between 1820 and 1992, while the Theil index increased by 60 percent in the same period. The process of strong convergence in economic growth among industrialized countries and divergence between groups of countries together with the take-off of China in the beginning of the I980s have been significant factors in determining the evolution of world inequality.

In estimating the distribution of income among individuals rather than countries, Bourguignon and Morrisson rely on real GDP per capita, population and the distribution of income summarized by 9 -deciles income shares and the top two ventile shares. They use the income shares multiplied by PPP-adjusted per capita GDP to derive world income distribution. They acknowledge the importance of taking into account demographic weights in shaping the evolution of the world distribution of income. Hence, the contribution of this paper lies in quantifying the importance of aggregate economic growth, population growth, and the structure of domestic income inequalities in explaining the evolution of the world distribution of income. Inequality is measured by the Gini coefficient, Theil index, mean logarithmic deviation and standard deviation of the logarithm. The limitation of such two-century studies lies however in the fact that the entire first century and the first half of the second century are based on very few observations on a few industrialized countries and is a poor representation of the world's population or incomes. Also a country observed within a region can be a poor proxy for other countries with missing observations that are located in the same region. The third issue is the low comparability and quality of the data over time.

In addition to the income dimension, Bourguignon and Morrisson consider non-income dimensions such as life expectancy in analyzing inequality in (economic) well-being. Average life expectancy has increased from 26.5 years in I820 to 6I.I in 1992. Differences in economic growth, demographic growth and changes in domestic income distribution are the principal factors contributing to world income inequality. The disequalizing factors are: the high economic performance of developed countries and especially Anglo-Saxon countries, the poor growth performances of rural China and India combined with their size effects, and the slow growth of Africa in the post-I950s period. The main equalizing factors are: income equalization within European countries, the catching up of European countries with the US after the Second World War and the 
high growth performances of the Asian Tigers and urban China since the I980s. The results of the analysis of inequality among world citizens are summarized as follows. First, world income inequality has exploded since the early nineteenth century. Second, the increase is because of the inequality among countries or regions rather than within countries. Third, inequality is not increasing but the concentration of poverty is increasing in some regions. And finally, the international disparity in life expectancy is increasing.

\section{Sala-i-Martin's Approach}

According to the fourth approach, Sala-i-Martin (2002a) uses aggregate GDP data and within-country income shares (although in some cases estimated income shares) for the period 1970-1998 to assign a level of income to each person in the world. He then estimates the kernel density function for the worldwide distribution of income, computes poverty rates for individual countries, and finally estimates global income inequality using seven different inequality indices. ${ }^{11}$ Overall inequality is decomposed into within- and between-country inequality components. The results show a reduction in global inequality between 1980 and 1998. Using the same data he estimates the poverty rates and headcounts for I25 countries (Sala-i-Martin 2002b). Assuming $\$ \mathrm{I} /$ day and $\$ 2 /$ day poverty lines he finds that overall poverty rates declined during the last 20 years. But while they declined in Asia and Latin America in 1980, they increased in Africa. A total of nine indices ${ }^{12}$ of income inequality were estimated. The results indicate substantial reductions in global income inequality during the I980s and I990s.

On a smaller regional scale, Londono and Szekely (2000) expand the Deininger and Squire (1996) data to assess changes in aggregate poverty and inequality in Latin America. Their empirical results are based on data from I3 Latin American countries observed during the period 1970 to 1995. Despite the differences in the levels across countries, inequality and poverty in most of the countries follow similar trends. Aggregate inequality increased during the 1970s, deteriorated further during the I 980 s and remained around the level registered in

11. The indices include: the Gini coefficient, the variance of log-income, two of Atkinson's indexes, the mean logarithmic deviation, the Theil index and the squared coefficient of variation.

12. In addition to the seven indices of income inequality listed in the previous footnote, the ratio of the average income of the top 20 percent of the distribution to the bottom 20 percent, and the ratio of the income of the persons located at the bottom of the top quintile divided by the income of the persons located at the top of the bottom quintile are estimated.
I990 during the I990s. The excess inequality (defined as the ratio of observed-toexpected inequality) is 25 percent and increasing over time. Lack of improvement in inequality is related to the non-pro-poor distribution of growth.

\section{E. Park's Approach}

Park (200I) examines trends in the global distribution of income defined as the real GDP per capita in 133 countries over the period $1960-1992$ using data from the Penn World Tables. The global population is divided into percentiles in terms of per capita income and he estimates the share of global income accruing to each percentile. The income shares are then used to estimate the global Gini coefficient for the 20 and io percentiles of the global population. Global income inequality here refers to the inequality among the nations of the world rather than the individuals of the world. It accounts for the population size of countries but neglects PPP. The key restrictive assumption is that all individuals of a country earn the same level of income and all countries constitute a single world economy. Results show that while the global distribution of income has not been more equal during the period of study as a whole, inequality declined during the period 1976-1992.

Recently Dikhanov and Ward (2002) in an attempt to reconstruct the complex nature of global income distribution during the later part of the twentieth century employed an intermediate aggregation approach labeled as a quasiexact interpolation technique. A combined micro (survey) and macro (national accounts) approach along with PPP is used to reconstruct the world's income distribution. The technique allows for the analysis of global income distribution by taking into account both within- and between-country inequalities and thus measuring inequality between average representative individuals. In analyzing the structure of global distribution and its regional composition and distributional changes over time a small sample of 45 countries for the selected periods I970, I980, I990 and 1999 is used. The results show that the partial global distribution has twin peaks: one concentrating around China, India and Africa, and another around the OECD countries indicating the absence of a middle class among the citizens of the world.

\section{Some Critiques of the above Approaches}

Results based on a few yearly observations are likely to be sensitive to the changing economic situation of countries. The uneven survey quality, the differences in the survey's definitions of income and expenditure, the assumption of equality of individuals within each decile, the problem of mixing income and expenditure, and the use of a single PPP exchange rate affect the quality of analy- 
sis. However, these studies might serve to establish the benchmark for the analysis of world inequality.

Bourguignon and Morrisson (2002) find the treatment of world inequality in international studies, like many of those mentioned above, in general oversimplifying because all citizens in a country (or population share) are considered as perfectly identical. As a consequence, the extent of inequality is underestimated by ignoring income disparity and the evolution of the distribution of income within countries (and income shares). The inference here is on international rather than world inequality biasing the view about the temporal patterns of world inequality. In their own approach the deciles represent individuals, i.e. instead of one representative individual ten representative individuals represent the country. Again here the within-decile variations are not accounted for.

The results in Dikhanov and Ward (2002) show that the partial global distribution has twin peaks indicating the absence of a middle class among the citizens of the world. Regardless of the partition level Milanovic and Yotzhaki (200I), using national income/expenditure distribution data from II9 countries find that the world lacks a middle class. A similar twin-peaks phenomenon was also observed earlier by Quah (1996). Sala-i-Martin (2002b) using income shares from 97 countries for the period 1970 to 1998 shows that by 1998 the twin peaks had vanished giving rise to a large middle class when one uses individual income data instead of aggregate country data. Over the 39-year period acute absolute poverty declined while under the broader definition of poverty the number of poor as well as global inequality increased.

A limitation of the study by Dikhanov and Ward (2002) compared with Milanovic (2002a) is the small sample size. Very little information is given about the micro-level data, namely the coverage and consistency of the data and the interpolation technique used. Capeau and Decoster (2003) explain the driving forces behind the differences in the two extreme positions in terms of whether inequality fell (Sala-i-Martin 2002a, 2002b) or rose (Milanovic 2002a, 2002b). They relate the diverging tendencies among others to three key factors: GDP per capita versus budget survey income measures used, the population-weighted inequality measures and the inequality among citizens irrespective of location.

\section{Summary of the World Individuals' Income Inequality}

There are a limited number of ways to construct world indices of income distribution and measure global income inequality reflecting both inequalities between and within countries. For a summary of several studies of global inequality see Appendix A where the combined micro and macro approach is often used. These studies differ largely by the extent and variations in the qual- ity of the micro data part. The standard data requirement to construct world income distribution is the mean income per capita complemented with the Gini coefficient, the standard deviation as measure of income dispersion, or direct information from household surveys by quintiles and deciles for individuals. Empirical results show that world inequality measured by the Gini coefficient increased from 0.50 in 1920 to 0.66 in 1992. Poverty, measured by headcount (percent) during the same period decreased from 94.4 to 51.3. The inequality based on a shorter period but with a better quality of data increased from 0.625 in 1988 to 0.659 in 1993.

Economic growth, population growth, life expectancy, and changes in the structure of income inequality are the most important factors in determining the evolution of world income distribution. Empirical results show also evidence of disparity in the development of life expectancy and economic growth. Inequality within individual countries is not increasing but inequality between countries and regions is increasing and the concentration of poverty is growing in some regions. Among the limitations of these studies are the short time period and the lack of income surveys with a satisfactory country population and a continuous time period coverage. Results are also often based on only a few observations and are sensitive to various data and the estimation method. Despite their limitations these studies can serve to establish a benchmark for the analysis of world income inequality and poverty.

\section{INTER-NATIONAL DISTRIBUTION OF INCOME}

International inequality refers to the distribution of income between countries. The common approach is to use the mean income or GDP per capita for individual countries complemented by the Gini coefficient or the standard deviation as a measure of income dispersion within each country and within-country income shares to construct income distribution for individual countries. In the following a brief review of the literature is presented and results are compared with those obtained from the WIID data.

\section{Between-Country Disparities}

As previously shown there is a comprehensive literature on the measurement of international inequality focusing on disparity between nations and very often on its relation with economic growth. As mentioned above, in several studies there is a certain degree of overlap between inequalities at different levels of aggregation. Sala-i-Martin (2002a) uses aggregate GDP data and within-country income shares to estimate the worldwide distribution of income, compute poverty rates and estimate global income inequality for the period 1970-1998. 
The poverty rates of $\$ \mathrm{I} /$ day and $\$ 2 /$ day fell during the period of the study from 20 to 5 percent and from 44 to 18 percent respectively. This poverty reduction corresponds to $300-500$ million people in 1998 . Inequality is decomposed into within- and between-country inequality components. In contrast to several studies reviewed previously, the results show also the reduction in global inequality between 1980 and 1998. Most global disparities reflect cross-country rather than within-country inequalities. The main source of between-country reductions is the growth in the Chinese economy. Within-country inequality has increased slightly. The lack of growth in African economies might cause further divergence and an increase in global inequality.

Unlike in Sala-i-Martin the results provided by Maddison (200I) show evidence of rising disparities in the world economy due to the divergence in economic performance across regions and countries over time. Bourguignon and Morrisson's (1999) study demonstrates that the increase in total inequality during the entire period of $1820-1990$ is driven by a rise in inequality between countries. Inequality between countries is the dominant factor in the evolution of world income inequality. Milanovic (2002a) in a comparison of income in 1988 and 1993 shows that between $75-88$ percent of inequality is attributed to the differences in mean income between countries and only $12-25$ percent is explained by the inequality within countries. As mentioned previously, Capeau and Decoster (2003) explain the driving forces behind the differences in the two extreme positions in terms of whether inequality fell or rose. They relate the diverging tendencies to income measures, the use of weights and the assumption of inequality among citizens irrespective of their location.

\section{Factors Affecting International Income Inequality}

Several factors have been identified and attempts made to quantify the impact they have on international income inequality. In the following we review a number of recent studies investigating the inequality effects of population weights on the Gini coefficient, the regional cost of living, openness, technology spillovers, specialization in production, economic growth, initial condition, skillbiased technology and wages, supply and demand of human capital and redistributive policies. The case in favor of a population-share weighted Gini is when countries or regions are aggregated. I do not see any case against a populationshare weighted Gini coefficient when applied in aggregated cases.

The international distribution of income based on Gini coefficients of national per capita GDP for 120 countries for the period 1950 to 1998 have been computed by Milanovic (200I). The temporal patterns of inequality differ according to whether or not the Gini coefficient is weighted by population. The unweighted Gini coefficient shows a decline in inequality between 1965 and 1978 and an increasing trend in international inequality after 1978. The increased inequality in Latin America, the jump in the inequality in Eastern Europe and the former USSR and the low performance of the African countries have contributed to the increased unweighted global inequality. The picture differs if the Gini coefficients are computed by weighting the GDP per capita by regional population shares. The weighted results show a declining world inequality due to the faster growth in the Indian and Chinese economies than in the world economy as a whole. However, the rapid economic growth has increased withincountry inequality in both countries. The increases in inequality are also found to be sensitive when market-based valuation methods are used and allowances are made for the differences in regional costs of living (Ravallion and Chen 1999; and Ravallion and Datt 2000).

Acemoglu and Robinson (2000) use the log of income per worker relative to the world average in 1990 against its I960 value to analyze the development and dispersion of world income distribution. Despite the large differences in income across countries, the dispersion of world income distribution has been relatively stable. They show that even in the absence of diminishing returns in production and technological spillovers, the degree of openness to international trade and the extent of specialization lead to a stable world income distribution. However, Milanovic (2002b) using data on PPP incomes from 90 countries around 1988 and 1993 shows that the effect of openness on a country's income distribution depends on the country's initial income level. Openness makes income distribution worse before making it better.

Acemoglu (2002) reviews the faster increase in the supply of skills in Europe and the role of Europe's labor market institutions in preventing wage inequality from increasing as the two most popular explanations for the different inequality trends in the US and the UK over the past decades. He identifies an additional factor to be the differences in the relative demand for skills. In Europe investment in technologies is encouraged by states increasing the productivity of less-skilled workers, reducing skill-biased technical change in Europe more than in the US. Eicher and Garcia-Penalosa (200I) argue that the stock of educated workers in an economy determines both the degree of income inequality and the rate of growth. They identify parameters that are central to the supply and demand of human capital ${ }^{13}$ and thus crucial for changes in inequality. Democratization and

13. Here changes in inequality depend on externalities in education, the evolution of the direct cost of education, the elasticity of substitution in production between skilled and unskilled workers, and the relative productivity and costs of learning by doing versus R\&D. 
political reforms through redistributive programs prevented widespread social unrest and revolution in Western societies in the nineteenth century with implications for the dynamics of growth and the fall in inequality (Acemoglu and Robinson 2000). However, the traditional public finance concerns about the excess burden of within-country income redistribution cannot explain why there is so little world redistribution (Kopczuk, Slemrod and Yitzhaki 2002).

In the early 1980 s a number of factors contributed to the increased interest in changes in distributional issues in the US in general and cross-national comparisons in particular. Gottschalk and Smeeding (1997) name three major factors: (i) studies showing the rising inequality of labor market income and its transformation into a greater inequality in the distribution of total family income; (ii) crossnational micro data became available for a variety of rich OECD countries; and (iii) the debate in the public policy arena over the fairness issue and the distributive effects of changes in government policies. In their review of the literature, they lay out a number of stylized facts and present summaries for both the level and the trend in earnings and income inequality. There are wide differences in inequality across countries, over time and across genders. Countries with centralized wage bargaining are more equal. Wage inequality is increasing over time and the trends differ across countries. It is affected by demand for skills, returns to education and experience and institutional constraints on wages. Disposable income (after taxes and transfers) is more equally distributed, but inequality has increased over time in most countries. The increased receipt of capital income and demographic and social changes played important roles in accounting for the rise in inequality in the OECD countries. Gottschalk and Smeeding search for a better structural model of income distribution and redistribution that can be applied across nations. It is concluded that an ideal model is a simultaneous model of generation of all sources of income and the formation of income sharing units.

\section{The WIID Data}

The data used here are obtained from the UNU-WIDER World Income Inequality Database (WIID), which is an expanded version of the Deininger and Squire (1996) database. The WIID contains information on income inequality, income shares, and a number of variables indicating the sources and the quality of data for 146 countries. The countries are observed on an irregular basis mainly during the period 1950-1998. To avoid distortions for graphing the trend in global income inequality over time the lower part of the data for 1950 is truncated. The number of excluded observations covering the period 1867-1949 is only 25 or 1.5 percent of the sample. A statistical summary of the WIID data is presented in Table I. ${ }^{14}$
The Gini coefficient is measured in percentage points. It is the mean of multiple observations for a country in a given year. The multiplicity of observations is due to the differences in income definitions, data sources, reference units, and population coverage. In constructing global inequality we have adjusted the Gini coefficient for the population as:

$$
\text { (2) } \quad \text { Gini }_{t}=\sum_{i=1}^{N}\left(\text { pop }_{i t} / \text { pop }_{t}\right) G i n i_{i t}=\sum_{i=1}^{N} p s_{i t} G i n i_{i t}
$$

where $p o p_{i t}$ is the population of country $i$ in period $t$, and $p s_{i t}$ the corresponding population share. Aggregate population in a given year $\left(p o p_{t}\right)$ is the reference population for the global population. However, since our sample does not cover all countries in the world in every year, it should be noted that the populationadjusted Gini measure based on the partial sample of countries is very sensitive to the exit and entry of countries with a large population like China and India. Furthermore, given that the Gini is not decomposable, it provides an aggregate measure of global inequality, which is also difficult to interpret. Although these are about within-country inequality the differences in inequality among the countries can be used to quantify the extent of between-country income inequality. A limitation however is that with the exception of population no other adjustments are made for data collection methodology or changing sample membership over time.

To provide a better picture of the distribution of world inequality and its development over time we report the unweighted mean, median, standard deviation and population-weighted mean Gini coefficient in Table 2 and also in Figure I. The decile observations are transformed into quintile income shares to make the income distribution comparable across countries and over time. This procedure results in a maximum number of comparable observations that can be obtained from the data but at the cost of losing information. In Figure 2 the mean quintile income shares over time are presented. As an alternative measure of inequality the ratio of the highest to the lowest quintiles is computed (see Table 3). The annual percentage changes in the unweighted mean Gini coefficient are also calculated and shown in Table 2. The development of the latter two measures is also shown in Figure 3.

\section{The Global Trend in Inequality Based on the WIID Data}

Simple descriptive statistics based on the WIID database are presented in Table I. The summary statistics of the Gini coefficient for observations with and

\footnotetext{
14. For a description of the WIID and other databases see Heshmati (2004f).
} 
Table 1 - Statistical Summary of the World Income Inequality Database (WIID)

\begin{tabular}{lrrrrr}
\hline Variable & Obs & Mean & Std Dev & Minimum & Maximum \\
\hline Gini Without Income Shares & 1376 & 38.110 & 10.910 & 15.900 & 79.500 \\
Gini With Income Shares & 1358 & 36.433 & 9.273 & 17.830 & 66.000 \\
Gini Without Sncome Shares & 1631 & 38.065 & 10.517 & 15.900 & 79.500 \\
Income Share Q1 & 844 & 0.069 & 0.036 & 0.016 & 0.157 \\
Income Share Q2 & 844 & 0.112 & 0.026 & 0.020 & 0.204 \\
Income Share Q3 & 844 & 0.157 & 0.025 & 0.070 & 0.255 \\
Income Share Q4 & 844 & 0.220 & 0.022 & 0.124 & 0.313 \\
Income Share Q5 & 844 & 0.441 & 0.082 & 0.249 & 0.710 \\
Q5/Q1 Ratio & 844 & 8.175 & 5.758 & 2.035 & 40.812 \\
\hline
\end{tabular}

Note: Gini coefficients with/without income shares refer to a combination of two observations for a country in a given year where one is with and the other without information on distribution of income.

without income share distributions are given both separately as well as jointly. The mean Gini coefficients for observations with income shares $(36.43)$ is lower than those without (38.II) income shares. There is a large variation in the distribution of income among the countries and over time. The income share of the poorest 20 percent varies in the interval 0.016 and 0.157 , with mean and standard deviations of 0.069 and 0.036 respectively. The income share of the richest 20 percent is $0.44 \mathrm{I}$ with a relatively small standard deviation of 0.082 . The disparity in income shares results in a Q5/Q1 ratio with a mean of 8.175 and a standard deviation of 5.758. The range varies within the interval 2.035 and 40.812 .

There is a large disparity in inequality over time (see Table 2). It is to be noted that the numbers here reflect the average of multiple observations for countries in a given year. The choice of measurement and the units of observation are not accounted for here. Therefore, the data lack uniform quality criteria and contain inconsistencies in distributions, definitions, sources, levels and coverage across countries and over time. If one chooses to consistently use a segment of the data with the same definitions of income, recipients and even the same welfare concept, the resulting sample will be very small and hardly sufficient to serve as a base for discussion of global trends in income inequality.

The median value of the Gini coefficients (37.74 percent) is on average I.5 percent lower than the mean value ( 39.02 percent). The mean, median, standard deviation, minimum, maximum and range of unweighted and mean-weighted Gini coefficient for the period 1950 to 1998 are presented in Table 2. There is a higher concentration of observations in the I990s. Figure I shows that the mean and the median inequality follow the same pattern and are declining over time. The dispersion in inequality also declines after 1958 .
Table 2 - Unweighted, Population Weighted and Percentage Changes in the Global Gini Coefficient over Time

\begin{tabular}{|c|c|c|c|c|c|c|c|c|c|}
\hline Year & Obs & Minimum & Mean & Median & Maximum & Std Dev & Range & Weighted & Change \\
\hline 1950 & 7 & 23.36 & 43.63 & 40.60 & 70.00 & 14.46 & 46.64 & 40.90 & -0.45 \\
\hline 1951 & 6 & 35.60 & 40.33 & 36.42 & 55.70 & 7.92 & 20.10 & 36.41 & -0.53 \\
\hline 1952 & 8 & 35.60 & 41.47 & 40.57 & 53.00 & 5.85 & 17.40 & 36.93 & 1.94 \\
\hline 1953 & 11 & 34.00 & 43.32 & 40.33 & 57.14 & 9.10 & 23.14 & 35.70 & -7.76 \\
\hline 1954 & 8 & 29.58 & 40.10 & 37.86 & 66.60 & 11.66 & 37.02 & 37.39 & 2.86 \\
\hline 1955 & 11 & 23.27 & 45.30 & 43.68 & 67.20 & 13.74 & 43.93 & 36.99 & 0.87 \\
\hline 1956 & 10 & 27.03 & 43.80 & 44.36 & 59.92 & 11.33 & 32.89 & 36.50 & -1.14 \\
\hline 1957 & 15 & 24.59 & 39.36 & 38.00 & 54.40 & 8.38 & 29.81 & 37.26 & 3.33 \\
\hline 1958 & 18 & 20.47 & 39.50 & 36.73 & 55.19 & 10.14 & 34.72 & 37.97 & -0.34 \\
\hline 1959 & 17 & 35.25 & 44.24 & 42.79 & 60.60 & 7.84 & 25.35 & 37.72 & 4.23 \\
\hline 1960 & 25 & 24.59 & 47.41 & 50.00 & 68.00 & 11.49 & 43.41 & 39.98 & 3.42 \\
\hline 1961 & 21 & 25.30 & 43.45 & 44.59 & 62.48 & 9.44 & 37.18 & 38.01 & -2.48 \\
\hline 1962 & 25 & 21.18 & 38.64 & 39.15 & 53.50 & 8.90 & 32.32 & 39.84 & -3.35 \\
\hline 1963 & 25 & 22.50 & 39.69 & 39.71 & 58.20 & 8.38 & 35.70 & 35.69 & -4.68 \\
\hline 1964 & 21 & 20.89 & 40.70 & 37.00 & 63.00 & 10.99 & 42.11 & 34.40 & 6.62 \\
\hline 1965 & 25 & 22.23 & 42.71 & 44.10 & 67.83 & 10.88 & 45.60 & 37.84 & 1.26 \\
\hline 1966 & 17 & 25.56 & 38.38 & 35.50 & 53.89 & 8.88 & 28.33 & 33.94 & -4.41 \\
\hline 1967 & 28 & 19.87 & 40.61 & 38.09 & 66.00 & 12.26 & 46.13 & 36.35 & -1.63 \\
\hline 1968 & 34 & 15.90 & 43.33 & 43.36 & 66.27 & 11.38 & 50.37 & 38.67 & 2.19 \\
\hline 1969 & 36 & 20.91 & 41.95 & 42.42 & 62.30 & 10.44 & 41.39 & 35.85 & 0.02 \\
\hline 1970 & 42 & 20.15 & 42.16 & 40.84 & 79.50 & 12.20 & 59.35 & 34.38 & 0.17 \\
\hline 1971 & 34 & 20.23 & 42.62 & 45.03 & 70.00 & 10.12 & 49.77 & 40.67 & -0.78 \\
\hline 1972 & 28 & 20.14 & 39.00 & 38.56 & 63.50 & 11.21 & 43.36 & 36.91 & 0.04 \\
\hline 1973 & 31 & 19.22 & 37.34 & 36.53 & 65.10 & 9.40 & 45.88 & 33.64 & 1.11 \\
\hline 1974 & 24 & 19.04 & 39.16 & 37.10 & 69.00 & 11.88 & 49.96 & 34.54 & -2.51 \\
\hline 1975 & 37 & 17.66 & 39.57 & 39.00 & 59.00 & 10.34 & 41.34 & 34.67 & -0.50 \\
\hline 1976 & 38 & 18.12 & 38.04 & 36.94 & 60.00 & 10.65 & 41.88 & 39.94 & 0.31 \\
\hline 1977 & 33 & 18.60 & 39.40 & 40.56 & 59.00 & 11.34 & 40.40 & 30.51 & 0.55 \\
\hline 1978 & 31 & 20.07 & 34.67 & 33.40 & 53.09 & 9.66 & 33.02 & 31.65 & -0.73 \\
\hline 1979 & 35 & 23.66 & 37.95 & 36.62 & 55.00 & 9.52 & 31.34 & 31.21 & 3.52 \\
\hline 1980 & 41 & 20.70 & 38.05 & 37.65 & 65.50 & 9.49 & 44.80 & 33.83 & -0.55 \\
\hline 1981 & 56 & 19.72 & 33.33 & 31.44 & 57.30 & 9.37 & 37.58 & 33.60 & -2.17 \\
\hline 1982 & 31 & 20.88 & 34.34 & 34.47 & 56.00 & 9.34 & 35.12 & 31.49 & 1.58 \\
\hline 1983 & 30 & 24.44 & 36.84 & 33.45 & 56.70 & 10.25 & 32.26 & 31.39 & 1.02 \\
\hline 1984 & 34 & 21.30 & 35.77 & 34.92 & 58.01 & 9.49 & 36.71 & 31.47 & 0.28 \\
\hline 1985 & 35 & 20.00 & 35.09 & 32.32 & 59.90 & 9.99 & 39.90 & 34.44 & -1.80 \\
\hline 1986 & 56 & 22.10 & 34.04 & 30.80 & 57.28 & 9.82 & 35.18 & 33.07 & 0.43 \\
\hline 1987 & 40 & 19.40 & 34.13 & 31.84 & 59.01 & 10.59 & 39.61 & 32.99 & 0.04 \\
\hline 1988 & 53 & 19.13 & 31.93 & 31.20 & 56.81 & 8.43 & 37.68 & 34.52 & 2.68 \\
\hline 1989 & 66 & 20.57 & 34.76 & 30.87 & 62.90 & 11.04 & 42.33 & 33.98 & -0.12 \\
\hline 1990 & 63 & 19.55 & 34.94 & 31.99 & 63.00 & 11.11 & 43.45 & 34.90 & 2.86 \\
\hline
\end{tabular}


Table 2 (Continued)

\begin{tabular}{rrrrrrrrrrr}
\hline Year & Obs & Minimum & \multicolumn{3}{c}{ Mean } & \multicolumn{3}{c}{ Median Maximum Std Dev Range Weighted Change } \\
\hline 1991 & 58 & 20.65 & 36.04 & 32.93 & 63.66 & 10.65 & 43.01 & 34.61 & 1.20 \\
1992 & 60 & 22.62 & 36.21 & 35.64 & 56.07 & 8.88 & 33.45 & 36.22 & 4.98 \\
1993 & 59 & 20.60 & 37.75 & 35.80 & 62.30 & 10.51 & 41.70 & 35.31 & 2.77 \\
1994 & 56 & 20.00 & 37.95 & 35.35 & 60.90 & 9.90 & 40.90 & 35.15 & 2.86 \\
1995 & 60 & 23.90 & 38.82 & 37.48 & 59.00 & 9.13 & 35.10 & 37.37 & 1.11 \\
1996 & 53 & 23.70 & 39.32 & 37.27 & 58.85 & 9.45 & 35.14 & 35.36 & 2.26 \\
1997 & 38 & 23.71 & 36.46 & 34.32 & 57.60 & 8.37 & 33.89 & 34.67 & 0.68 \\
1998 & 15 & 25.30 & 37.72 & 37.75 & 59.11 & 8.70 & 33.82 & 40.12 & 3.66 \\
Mean & $\mathbf{4 9}$ & $\mathbf{2 3 . 0 5}$ & $\mathbf{3 9 . 0 2}$ & $\mathbf{3 7 . 7 4}$ & $\mathbf{6 0 . 4 8}$ & $\mathbf{1 0 . 0 9}$ & $\mathbf{3 7 . 4 3}$ & $\mathbf{3 5 . 6 5}$ & $\mathbf{0 . 5 0}$ \\
\hline
\end{tabular}

Note: Mean, median, standard deviation, minimum and maximum Gini values are based on the unweighted country observations (obs) of the Gini coefficient in a given year, while weighted is the mean value of the population weighted Gini coefficient. The population share is defined as the share of total population of countries observed in a given year. The percentage change (change) is based on the unweighted Gini.

Figure 1 - Global Trends in Income Inequality

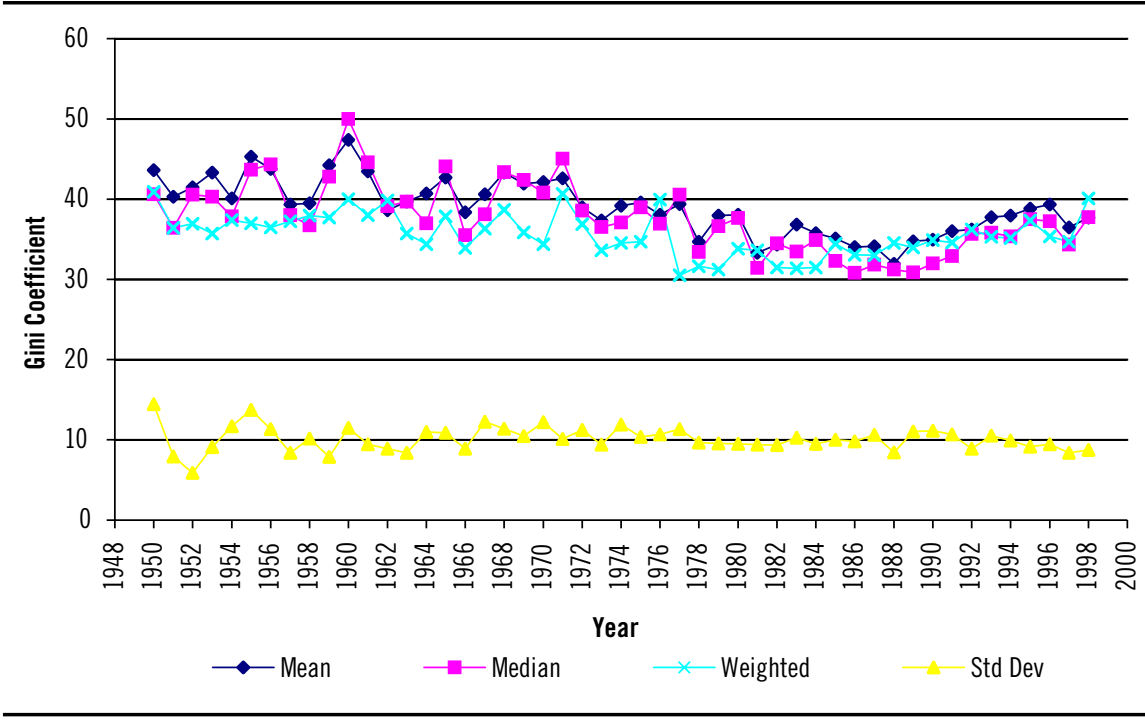

The highest mean inequality values exceeding 55 percent are found among the African countries (the Central African Republic, Gabon, Kenya, Lesotho, Sierra Leone, Swaziland and Zimbabwe) and some Latin American countries exceeding 50 percent (Bolivia, Brazil, Chile, Colombia and Honduras). The high levels of Gini, and their concentration in conjunction with low average incomes
Figure 2 - Development of Global Income Shares

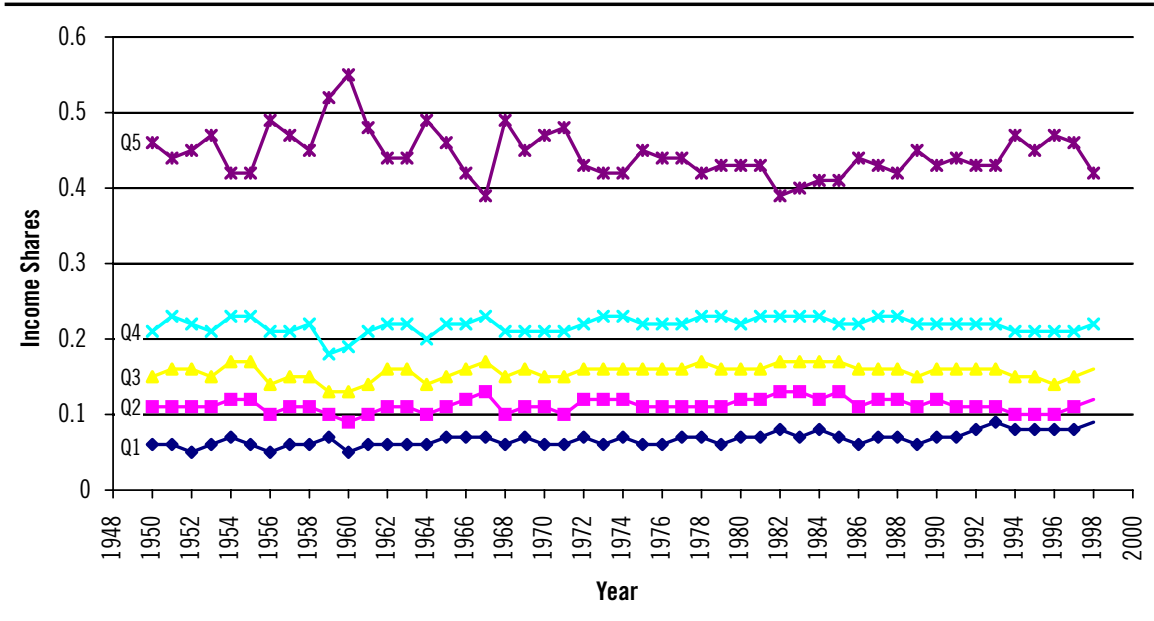

are disastrous for aggregate welfare. The average range between maximum and minimum values observed for a country over time is 37.43 percent and the standard deviation is 10.09 percent. A number of countries show quite large ranges of percentage variations, among others China, Brazil, Cuba, Guatemala, Jamaica, Morocco, Zimbabwe, Georgia, Finland, the Netherlands, Spain, and the UK.

In the measurement of global or regional inequality it is a common practice to weight inequality by population. The population-weighted mean Gini coefficient is much lower ( 35.65 percent) than the non-weighted ( 39.02 percent). The drop is caused by the inclusion of countries with large populations and relatively low inequalities. Though India and China are frequently observed, the weighing procedure is not reliable, as the flow of population is very irregular over time. The average change in the Gini coefficient is 0.50 percent indicating a small positive trend in non-weighted inequality over time. The change in the Gini coefficient varies in the interval -7.76 (1952/1953) to +6.62 (1963/1964) percent (see Figure 3 and Table 2). The shifts in the temporal patterns of the Gini coefficient over the recent 50 years show that a simple time trend is not an appropriate way of modeling global trends in income inequality.

The distribution of income measured by quintile shares shows a large variation across countries and over time. The mean income quintile shares are 0.069, $0.112,0.157,0.220$ and $0.44 \mathrm{I}$ (see Table 3). The lowest quintile share shows a constant pattern prior to 1990 but increasing patterns after the 1990 period. The highest 3 quintiles show, on the other hand, variations before 1970 but a decreasing pattern in the period after the I970s (see Figure 2). This resulted in a continuously increasing inequality change over time combined with a declining Q5/QI 
Table 3 - Development of the Global Gini Coefficient and the Distribution of Income Share over Time.

\begin{tabular}{|c|c|c|c|c|c|c|c|c|c|}
\hline Year & Obs & Unweighted & Weighted & d $Q 1$ & Q2 & Q3 & Q4 & Q5 & Q5/Q1 \\
\hline 1950 & 7 & 43.63 & 40.90 & 0.06 & 0.11 & 0.15 & 0.21 & 0.46 & 7.12 \\
\hline 1951 & 6 & 40.33 & 36.41 & 0.06 & 0.11 & 0.16 & 0.23 & 0.44 & 7.65 \\
\hline 1952 & 8 & 41.47 & 36.93 & 0.05 & 0.11 & 0.16 & 0.22 & 0.45 & 8.72 \\
\hline 1953 & 11 & 43.32 & 35.70 & 0.06 & 0.11 & 0.15 & 0.21 & 0.47 & 7.62 \\
\hline 1954 & 8 & 40.10 & 37.39 & 0.07 & 0.12 & 0.17 & 0.23 & 0.42 & 6.33 \\
\hline 1955 & 11 & 45.30 & 36.99 & 0.06 & 0.12 & 0.17 & 0.23 & 0.42 & 6.89 \\
\hline 1956 & 10 & 43.80 & 36.50 & 0.05 & 0.10 & 0.14 & 0.21 & 0.49 & 10.20 \\
\hline 1957 & 15 & 39.36 & 37.26 & 0.06 & 0.11 & 0.15 & 0.21 & 0.47 & 7.61 \\
\hline 1958 & 18 & 39.50 & 37.97 & 0.06 & 0.11 & 0.15 & 0.22 & 0.45 & 7.39 \\
\hline 1959 & 17 & 44.24 & 37.72 & 0.07 & 0.10 & 0.13 & 0.18 & 0.52 & 7.43 \\
\hline 1960 & 25 & 47.41 & 39.98 & 0.05 & 0.09 & 0.13 & 0.19 & 0.55 & 12.15 \\
\hline 1961 & 21 & 43.45 & 38.01 & 0.06 & 0.10 & 0.14 & 0.21 & 0.48 & 7.79 \\
\hline 1962 & 25 & 38.64 & 39.84 & 0.06 & 0.11 & 0.16 & 0.22 & 0.44 & 7.24 \\
\hline 1963 & 25 & 39.69 & 35.69 & 0.06 & 0.11 & 0.16 & 0.22 & 0.44 & 7.03 \\
\hline 1964 & 21 & 40.70 & 34.40 & 0.06 & 0.10 & 0.14 & 0.20 & 0.49 & 8.26 \\
\hline 1965 & 25 & 42.71 & 37.84 & 0.07 & 0.11 & 0.15 & 0.22 & 0.46 & 7.03 \\
\hline 1966 & 17 & 38.38 & 33.94 & 0.07 & 0.12 & 0.16 & 0.22 & 0.42 & 5.82 \\
\hline 1967 & 28 & 40.61 & 36.35 & 0.07 & 0.13 & 0.17 & 0.23 & 0.39 & 5.26 \\
\hline 1968 & 34 & 43.33 & 38.67 & 0.06 & 0.10 & 0.15 & 0.21 & 0.49 & 8.62 \\
\hline 1969 & 36 & 41.95 & 35.85 & 0.07 & 0.11 & 0.16 & 0.21 & 0.45 & 6.86 \\
\hline 1970 & 42 & 42.16 & 34.38 & 0.06 & 0.11 & 0.15 & 0.21 & 0.47 & 7.72 \\
\hline 1971 & 34 & 42.62 & 40.67 & 0.06 & 0.10 & 0.15 & 0.21 & 0.48 & 8.22 \\
\hline 1972 & 28 & 39.00 & 36.91 & 0.07 & 0.12 & 0.16 & 0.22 & 0.43 & 5.91 \\
\hline 1973 & 31 & 37.34 & 33.64 & 0.06 & 0.12 & 0.16 & 0.23 & 0.42 & 6.68 \\
\hline 1974 & 24 & 39.16 & 34.54 & 0.07 & 0.12 & 0.16 & 0.23 & 0.42 & 6.35 \\
\hline 1975 & 37 & 39.57 & 34.67 & 0.06 & 0.11 & 0.16 & 0.22 & 0.45 & 7.23 \\
\hline 1976 & 38 & 38.04 & 39.94 & 0.06 & 0.11 & 0.16 & 0.22 & 0.44 & 6.97 \\
\hline 1977 & 33 & 39.40 & 30.51 & 0.07 & 0.11 & 0.16 & 0.22 & 0.44 & 6.63 \\
\hline 1978 & 31 & 34.67 & 31.65 & 0.07 & 0.11 & 0.17 & 0.23 & 0.42 & 6.09 \\
\hline 1979 & 35 & 37.95 & 31.21 & 0.06 & 0.11 & 0.16 & 0.23 & 0.43 & 7.02 \\
\hline 1980 & 41 & 38.05 & 33.83 & 0.07 & 0.12 & 0.16 & 0.22 & 0.43 & 6.39 \\
\hline 1981 & 56 & 33.33 & 33.60 & 0.07 & 0.12 & 0.16 & 0.23 & 0.43 & 6.57 \\
\hline 1982 & 31 & 34.34 & 31.49 & 0.08 & 0.13 & 0.17 & 0.23 & 0.39 & 5.11 \\
\hline 1983 & 30 & 36.84 & 31.39 & 0.07 & 0.13 & 0.17 & 0.23 & 0.40 & 5.51 \\
\hline 1984 & 34 & 35.77 & 31.47 & 0.08 & 0.12 & 0.17 & 0.23 & 0.41 & 5.40 \\
\hline 1985 & 35 & 35.09 & 34.44 & 0.07 & 0.13 & 0.17 & 0.22 & 0.41 & 5.56 \\
\hline 1986 & 56 & 34.04 & 33.07 & 0.06 & 0.11 & 0.16 & 0.22 & 0.44 & 6.91 \\
\hline 1987 & 40 & 34.13 & 32.99 & 0.07 & 0.12 & 0.16 & 0.23 & 0.43 & 6.45 \\
\hline 1988 & 53 & 31.93 & 34.52 & 0.07 & 0.12 & 0.16 & 0.23 & 0.42 & 6.19 \\
\hline 1989 & 66 & 34.76 & 33.98 & 0.06 & 0.11 & 0.15 & 0.22 & 0.45 & 7.14 \\
\hline 1990 & 63 & 34.94 & 34.90 & 0.07 & 0.12 & 0.16 & 0.22 & 0.43 & 5.95 \\
\hline
\end{tabular}

\begin{tabular}{lccccccccc}
\hline Year & Obs & \multicolumn{1}{c}{ Unweighted Weighted Q1 } & Q2 & Q3 & Q4 & Q5 & Q5/Q1 \\
\hline 1991 & 58 & 36.04 & 34.61 & 0.07 & 0.11 & 0.16 & 0.22 & 0.44 & 6.52 \\
1992 & 60 & 36.21 & 36.22 & 0.08 & 0.11 & 0.16 & 0.22 & 0.43 & 5.36 \\
1993 & 59 & 37.75 & 35.31 & 0.09 & 0.11 & 0.16 & 0.22 & 0.43 & 5.06 \\
1994 & 56 & 37.95 & 35.15 & 0.08 & 0.10 & 0.15 & 0.21 & 0.47 & 6.08 \\
1995 & 60 & 38.82 & 37.37 & 0.08 & 0.10 & 0.15 & 0.21 & 0.45 & 5.74 \\
1996 & 53 & 39.32 & 35.36 & 0.08 & 0.10 & 0.14 & 0.21 & 0.47 & 6.20 \\
1997 & 38 & 36.46 & 34.67 & 0.08 & 0.11 & 0.15 & 0.21 & 0.46 & 5.93 \\
1998 & $\mathbf{1 5}$ & 37.72 & 40.12 & 0.09 & 0.12 & 0.16 & 0.22 & 0.42 & 4.86 \\
Mean & $\mathbf{4 9}$ & $\mathbf{3 9 . 0 2}$ & $\mathbf{3 5 . 6 5}$ & $\mathbf{0 . 0 7}$ & $\mathbf{0 . 1 1}$ & $\mathbf{0 . 1 6}$ & $\mathbf{0 . 2 2}$ & $\mathbf{0 . 4 5}$ & $\mathbf{6 . 8 0}$
\end{tabular}

Note: The weighted Gini coefficient refers to the population-weighted mean value calculated based on the country observations in a given year. The Q1-Q5 are quintile income shares. The ratio $\mathrm{Q} 5 / \mathrm{Q} 1$ is a measure of the extent of income share inequalities in the world.

ratio (see Figure 2). The highest ratios are associated with countries involved in (domestic) conflicts like Iraq, Lebanon, Paraguay, the Central African Republic, Guinea, Sierra Leone, South Africa and Georgia, while the lowest are associated with Egypt, Laos, Belarus and Luxembourg.

Considering the global trends, due to the strong influence of the highest quintile income share, inequality is volatile prior to 1970 and more stable and increasing over the course of the post-I986 period. There is evidence of the convergence in the mean, median and population-weighted means over time (see Figure I). In sum based on the WIID data, applied measurement methods and data irregularities, there is no convincing sign of a significantly increasing or decreasing global trend in income inequality over the last 50 years. It should be noted that the inequality here is based on only within-country inequality data but are pooled and weighted such that the level differences reflect international inequality. The trend accounting for between-country inequality may be different.

\section{Summary of International Income Inequality}

International inequality refers to economic disparity between countries of the world. Appendix B presents a summary of several studies of international income inequality. The international distribution of income is often based on the Gini coefficient of national per capita GDP. The temporal patterns of inequality differ according to whether or not the Gini is weighted by the population of the countries. The results from a weighted Gini coefficient show that world inequality has declined due to the faster growth in India and China than in the world 
Figure 3 - Development of Changes in the Global Gini Coefficient and Q5/Q1 Ratio

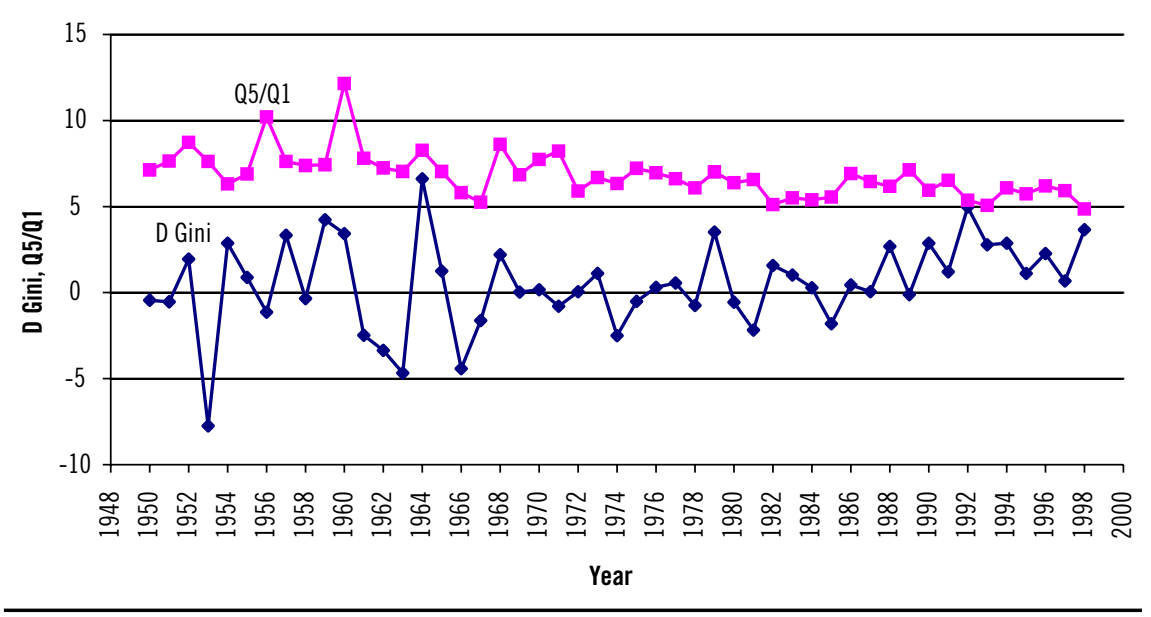

economy as a whole but at the cost of an increased within-country inequality. The long-run world income distribution involves substantial improvements in the income of many countries. Divergence in economic performance across regions and economies over time raises the question of disparity in the world economy. Lack of growth in the African economies causes divergence and an increase in global inequality. In sum total inequality is driven by a rise in inequality between countries affecting the evolution of world income inequality. Important factors affecting convergence or divergence in the international income gap are mass migration, barriers to migration, trade and capital flows. Political economy factors affect intertemporal (within-country) variations in inequality, while capital market imperfections affect international (between-country) variations in inequality.

Considering the global trends in income inequality, results based on the WIID database show that inequality is volatile prior to 1970 and more stable with tendencies to increase after 1986. The overall pattern is very much similar to the patterns of the highest quintile income share. However, there is no convincing sign of a significant global trend in income inequality over the last 50 years. The inequality measure here is based on only within-country inequality. The trend in between-country inequality may be different. The cross-section of time-series data on inequality and income distribution using the Pyatt-type decomposition approach (Equation I) described above could be used here to decompose overall inequality into within-country, between-country and overlapping components as was done by Milanovic (2002a).

\section{INTRA-NATIONAL DISTRIBUTION OF INCOME}

\section{Inequality Within Countries}

The measurement of income distribution at the national level discussed here is based on aggregate data. Part of the information is taken from our review of a number of international studies. Research on within-country or intra-national inequality based on micro household data is not discussed in this section for the reason of limited space. ${ }^{15}$

As shown in the previous two sub-sections most of the research analyzing changes in income distribution during the post-World War II period concluded that income inequality within countries tends to be more stable over time, while between-country inequality is more variable and derives from the level and temporal patterns of world income inequality. This is interpreted as the lack of a strong association between growth and within-country inequality making poverty reduction through growth-oriented policies more possible than redistributive policies. This view is challenged by Cornia (1999) and associates in a number of studies by referring to the decline in inequality in several nations between the I950s and I970s and an increase in inequality in two-thirds of their sample of 77 countries during the last twenty years. Cornia suggests that the factors explaining the rise in income inequality are related to: shifts towards skill-intensive technologies, liberalization of domestic and international markets, decline in labor share during structural adjustment, trade liberalization, rise in financial rents, privatization of state assets, distribution of industrial assets, changes in labor institutions, and changes in the tax and transfer systems.

In a related study Cornia and Court (200I) report changes in within-country income inequality over time and discuss the link between poverty, inequality and growth. In addition to what are traditionally seen as the most common factors causing inequality such as land concentration, urban bias and inequality in education, a number of new causes of inequality ${ }^{16}$ are discussed while various policy measures to counteract inequality are also provided. De Gregorio and Lee (2002) present empirical evidence on how education is related to a coun-

15. The results of within-country inequality in selected large countries are found in Heshmati (2004e).

16. In discussing major new causes of inequality they account for trade liberalization, technological change, stabilization and adjustment programs in developing countries, financial liberalization, privatization and the distribution of industrial assets, and changes in the labor market institutions, tax and transfer systems. 
try's income distribution. The findings suggest that higher educational attainment and a more equal distribution of education makes income distribution more equal. Commander, Tolstopiateniko and Yemtsov (1999) point to wealth transfers through privatization programs, changes in government expenditures, growth in earnings dispersion, and shifts in the structure of income as the driving forces behind the increase in inequality in Russia. Fan, Overland and Spagat (1999) propose an immediate restructuring of the education system in Russia in an effort to reduce inequality.

Several studies show that between-country inequality explains a bigger share of inequality. Cornia and Kiiski (200I) advocate that from a policy perspective it is more important to focus on within-country inequality because the former is path-dependent and takes several generations to modify, while in the later case policy decisions affecting inequality are taken at the national level. Lindert and Williamson (200I) find that inequality has been driven by between-country rather than within-country income differences. However, heterogeneity in the magnitude of within-country effects is due to the factors of land and labor and the participant country's policies to exploit the benefits of globalization. During the interwar period inequality between countries accelerated.

In sum the analysis of within-country income inequality is best studied based on representative micro-household surveys. These are not discussed here. It is much easier to influence within-country inequality by policy decisions than between-country international inequality under weak international institutions. The most commonly accepted factors causing within-country inequality are identified in general to be land concentration, urban-biased development, the ageing of the population and inequality in education. The last two factors are more important in the context of developed economies. During a transition period wealth transfers during privatization programs, changes in government expenditure and shifts in the structure of income may also increase inequality. The major new causes of inequality associated with external relations are trade and financial liberalization, technological change, stabilization and adjustment programs. However, the increase in inequality following the above changes may be transitory in nature. The degree to which increased inequality remains persistent will to some extent depend on how active the counties studied are in their (tax and transfer) redistributive policies.

\section{Stability and Convergence of Income Inequality}

$\mathrm{Li}$, Squire and Zou (1998) explore the relative stability of income inequality within countries over time and the significant variability among countries. The results suggest that inequality is largely determined by factors that change slowly within countries but are quite different across countries. The Gini coefficients are clearly different across countries and there is no evidence of a time trend in 65 percent of the unbalanced panel of 49 countries used. The stability in the intertemporal variation in inequality is affected positively by political economy factors (the presence of civil liberties and the initial level of secondary schooling), while the international variation in inequality is increasing in capital markets (the extent of financial depth and the initial distribution of land). The regression analysis of the variance of the Gini coefficient shows that after an adjustment for the differences in income definitions more than 92 percent of the total variation is explained by country-specific effects.

Jones (1997), in characterizing the evolution of world income distribution, uses three different techniques. First, he uses a standard growth model and takes as given conditions in the 1980 os in order to project the current dynamics of income distribution forward. Results indicate small changes in the top of the income distribution. Second, following the insights from the cross-country growth literature, he interprets the variation in growth rates around the world as reflecting how far countries are from their steady state positions and predicts where countries are headed. Third, Jones considers how steady states are themselves changing over time. The increasing relative frequency of growth miracles indicates that the fraction of poor countries is falling and he projects that the long-run world income distribution involves substantial improvements in the incomes of many countries.

As a guideline for future research, in my view by using an approach similar to that found in the frontier literature changes in income distribution or distances to the steady state could easily be disaggregated into changes in the distribution of income over time and changes in the steady state to estimate the rates at which specific countries catch up.

There are several studies on convergence in income inequality. The most useful are those examining convergence in inequality among countries within an integrated economic region or members of an economic union. The concept of convergence in income inequality (Benabou 1996) follows that of the conditional convergence of per capita income (e.g. Mankiw, Romer and Weil I992). Iacoviello (1998) using LIS data investigates whether inequality converges to a steady state level of inequality during the process of income growth. Results show that shocks to income yield short-run effects on income distribution. A reversal link from inequality to income was not observed. Acemoglu and Robinson (2000) in their analysis of the development and dispersion of the distribution of world income show that the increased openness to international trade and specialization lead to a stable world income distribution. 


\section{FACTORS AFFECTING THE WORLD DISTRIBUTION OF INCOME}

The literature on the distribution of income and income inequality identifies a number of factors that are important for the evolution of world income distribution. A summary of factors affecting the shape of the world distribution of income found in the literature is given in Appendix C. In this section we briefly introduce the arguments and empirical results on factors such as inheritance, wage inequality, supply of skills, labor market institutions, mobility, redistributive policies, growth, globalization, democracy, geography and institutions. ${ }^{17}$

The initial inequality related to parents and family environment affects education, opportunities, welfare and success rates of individuals in their lives. The study by Bowles and Gintis (2002) is one recent example where evidence from the contribution of environmental, genetic and wealth effects to intergenerational transmission of economic position is shown. For instance, the parental income and wealth of an American are strong predictors of the likely economic status of the next generation. However, in the following we focus on the factors affecting inequality at a more aggregate level than individuals, households or sub-groups of the population.

\section{Trade Liberalization}

Wage inequality has increased less in Europe than in the US and the UK for the same period (Lindert and Williamson 200I). The non-uniform increase in wage inequality among industrialized countries suggests that labor market policy matters. The 'transatlantic consensus' (Atkinson 1999) sees rising inequality as the product of exogenous, inevitable events. Wage inequality in OECD countries or unemployment is increasing on account of technical change biased against unskilled workers or on account of the liberalization of international trade and the increased competition from newly industrializing countries. Technology and reforms may change the size of the wage gap.

Atkinson's alternative approach sees inequality in part as socially generated related to the wage/productivity relationship and changes in labor markets,

17. The discussion here is related to factors that affect both within-country and between-country inequalities. It would be useful to broadly differentiate between factors affecting each of these two components while also allowing for their overlapping factors. It is desirable that emphasis should then be given to systematic discussion of colonialism, institutions and governance, international trade, international debt, defense spending, structural adjustments, and international aid. This will allow for heterogeneous perspectives on the problem. However, such systematic discussion is beyond the scope of this paper. rather than trade or technology factors. Atkinson's view about rising inequality is in contrast to the widely held belief that it is an unavoidable consequence of the present revolution in information technology or the globalization of trade and finance. Redistributive policy measures of governments can counteract the rise in market income inequality.

The two most popular explanations for these differential trends are that the relative supply of skills has increased faster in Europe, and European labor market institutions in different ways have prevented inequality from increasing. In relation to the effects of trade liberalization Fischer (200I) presents a general framework for the analysis of the evolution of the distribution of personal income following trade liberalization. Here wages determine the short-run, and interest rates the long-run evolution of inequality. Production factors and types of exports determine the effects of liberalization on inequality.

Wood and Ridao-Cano (1999) using data from 90 countries during 1960-90 find that greater openness tends to cause divergence of secondary and tertiary enrolment rates between more-educated and less-educated countries, and also between land-abundant (such as sub-Saharan African) and land-scarce countries.

\section{Skills and Earnings}

Acemoglu (2002) finds that the two traditional explanations (supply of skills and labor market institutions) of the different trends in inequality do not provide an entirely satisfactory explanation. A third explanation is that the relative demand for skilled labor has increased differently across countries (see also Williamson 1996). Wage compression and the encouragement of more investment in technologies have increased the productivity of less-skilled workers, implying a less-skilled-biased technical change in Europe than in the US.

In relation to the analysis of inequality, economic growth and mobility Gottschalk (1997) presents some basic facts on how the distribution of earnings and employment has shifted. In a case with multi-period earnings, the inequality in each sub-period and the mobility across sub-periods would both impact the inequality of the permanent (or average) earnings of individuals. The relation incorporating price adjustments indicates that individual year variances (inequality) and cross-year covariances (mobility) affect the variance of average income. There is a controversy over the explanation of these patterns. In the US there has been an increase in the demand for, and in the relative price of skilled labor. The decline in the wages of less-skilled laborers has resulted in unchanged average wages but earnings inequality has increased. Earnings inequality has however increased less due to labor market institutions and redistributive policies in Nordic and northern European countries than in other developed countries. 
Variations in the distribution of skills and earnings among the major English-speaking countries (US, UK and Canada) and continental European Union countries raise the possibility that the differences in the distribution of skills determine income inequality. Empirical results by Devroye and Freeman (200I) based on data from eleven advanced countries show that skill inequality explains only 7 percent of the cross-country inequality differences. Most inequality is related to the within-skill groups generated from the pay mechanism, rather than the between-skill groups.

\section{Growth and Redistributive Policies}

Acemoglu and Ventura (2002) offer an alternative framework to the new classical growth model for analyzing world income distribution. They show that even in the absence of diminishing returns in production and technological spillovers, international trade based on specialization leads to a stable world income distribution. Specialization in trade reduces prices and the marginal product of capital and introduces diminishing returns. Concerning the role of institutions there is evidence that countries colonized by European powers that were relatively rich in 1500 are now relatively poor. This reversal is inconsistent with the view that links economic development to geographic factors, but consistent with the role of institutions in economic development. European intervention created an institutional reversion by encouraging investment in poor regions. The institutional reversal accounts for the reversal in relative incomes during the nineteenth century. Diverging societies with good institutions for their economic development took advantage of industrialization opportunities (Acemoglu, Johnson and Robinson 2002).

Atkinson (2000) has examined the redistributive impacts of government budgets in six OECD countries ${ }^{18}$ over the period from 1980 to the mid-I99os. All countries experienced a rise in inequality of market income but differed both across countries and over time with regards to the distribution of disposable income. In reviewing the actual government policy responses by taking unemployment benefits and personal income taxation as case studies, the changes to policy parameters differed in extent and even in direction. However, no clear pattern was found in the nature of the relationship between inequality and redistribution. In a global perspective inequality reflects both elements of within- and between-country income inequality components. The within-country com-

18. The countries include the United Kingdom, Canada, West Germany, Finland, Sweden and the United States. ponents can be affected through policy interventions, but such interventions designed to affect global income inequality have proved to be a difficult task to co-ordinate (Cornia and Court 200I).

Integration and its links to economic growth, poverty reduction and increasing inequality are important issues which are often addressed. Quah (200I) addresses several questions in his study of economic growth and income inequality. The two main questions asked are: how quantitatively important is the causal relation and why should that relation matter? Improvements in living standards overwhelm any deterioration due to increases in inequality. Other forces through their impact on aggregate growth will also affect the poor - independently of the effect of inequality on the economic growth. Furthermore, the uses of the Gini coefficient might not reflect the true nature of inequality. Quah (2002) shows that neither of these possibilities (that growth causes inequality and the poor might be disadvantaged) is empirically testable for China and India. The findings indicate that only under inconceivably high increases in inequality would economic growth not benefit the poor, and the way inequality causes growth is empirically irrelevant for determining outcomes for individual income distributions. With reference to Dollar and Kraay's (200I) evidence on the gains and losses of growth to the poor, Ravallion (200I) finds large differences between and within countries on the impact of growth on the poor. Ravallion expresses the need for a deeper micro-empirical work on growth and distributional change to identify specific policies to complement growth-oriented policies.

A view that any inequality-promoting effect of growth is unlikely to be large enough in magnitude to swamp the beneficent effect of growth on poverty is not probably sufficient cause to concentrate on growth as the engine of poverty reduction. Growth combined with redistributive measures or simply redistributive measures alone could also reduce poverty.

\section{Globalization}

Globalization through the integration of economies and societies has been considered as a powerful force for economic development and poverty reduction. Although integration presents opportunities to reduce poverty, it also contains a significant risk of increasing negative effects like inequality, polarization, shifting power, cultural dominance and uniformity (Dollar and Kraay 200I; Dollar and Collier 200I).

The period $1870-2000$ is classified into: the first wave of globalization $1870-$ 1913, the de-globalization period of 1913-1950, the golden age of 1950-1973, and the second wave of globalization of 1973 onwards (see O'Rourke and Williamson 2000; O'Rourke 200I; Maddison 200I). The empirical evidence shows that 
during the first wave of globalization the convergence in per capita income and real wages took place within the Atlantic economies due to an increase in international trade and massive international migration. The de-globalization period is characterized by a widening disparity between the richest and the poorest regions and among the Atlantic economies. The golden age period is seen as a time of rapid growth, relative stability and declining inequality.

In recent years, research on the link between globalization and world inequality has been intense. Three main approaches are distinguished (Wade 20orb). First, neoclassical growth theory says that national economies will converge in their average productivity levels and average incomes because of the increased mobility of capital. Second, endogenous growth theory states that diminishing returns to capital are offset by increasing returns to technological innovation in the developed countries. It is to be noted that neoclassical theory predicts convergence (equality) while the endogenous theory predicts less convergence or divergence (inequality). Third, proponents of the dependency approach maintain that convergence is less likely and divergence more likely because of the differential benefits from economic integration and trade, restricted free market relations, and the fact that developing countries are often locked into producing certain kinds of commodities.

The channels through which globalization affects world inequality are identified by Wade (20orb) to be: commodity price equalization, factor price convergence due to international migration and capital mobility reducing wage inequality and differentials in marginal products and rates of returns of capital among countries, and the dynamic convergence in per capital income growth where the growth rate is positively related to the distance to the steady state.

During the golden age period there was a considerable convergence among Western European economies and OECD countries and a decline in the GDP gap in per capita income between the poorest and the richest regions (see Solimano 200I). In his survey of trends in both international economic integration and inequality over the past 150 years, O'Rourke (200I) distinguishes between the different dimensions of globalization and within- and betweencountry inequality. Nineteenth-century globalization had large effects on withincounty income distribution, but also heterogeneous effects on inequality across countries making rich countries more unequal. The twentieth-century evidence on such links is however mixed.

Mahler (200I) studies the issues of economic globalization, domestic politics and income inequality in developed countries in a pooled regression analysis using an unbalanced panel of LIS data on I4 countries where each is observed between I to 3 periods during the 198I-1992 time-frame. This approach differs from the dependency approach of Wade. ${ }^{19}$ The results show little evidence of a systematic relationship between any of the three main modes of economic globalization (trade, foreign direct investment and financial openness) and either the distribution of disposable income or the earnings of households. The overall conclusion is that integration into the world economy does not systematically lead to an egalitarian distribution of income or earnings across entire economies. The modes of globalization are weakly and positively related to the fiscal redistribution in the countries studied. Politics continues to play a critical role in determining the distributive outcomes in the developed world. Economic globalization is compatible with a wide variety of political interactions leading to a wide range of distributive outcomes.

With reference to a number of studies such as Milanovic (2002a) and Dikhanov and Ward (2002), Wade (2001a and 2001b) argues that the global distribution of income is becoming ever more unequal. Inequality is increasing faster than hitherto suspected, and for Wade governments should respond and be more proactive. In sum the studies reviewed here indicate that globalization has been a force for between-country divergence. The unequal distribution of industrialization has been an important factor promoting divergence. ${ }^{20}$

Democracy and the institutional structure of international society are also expected to have a relationship with income inequality. In a survey of the empirical relationship between democracy and inequality Gradstein and Milanovic (2002) based on results from the transition economies show that there are some indications regarding a positive relation between democracy and inequality. Hurrell (200I) considers the link between international institutions and global economic justice. The institutional structure of international society has developed but continues to constitute a deformed order. Hurrell examines why international distributive justice remains so marginal to the current practice.

Heshmati $(2003 ; 2004 \mathrm{~g})$ presents measurement of a multidimensional index of globalization. The index is composed of four main components: economic integration, personal contact, technology, and political engagements, each developing differently over time. This breakdown of the index into major components makes

19. The dependent variable is defined in three different ways as: (i) the 9o/ Io ratio of size-adjusted disposable household income, (ii) the 90/ Io ratio of earnings inequality, and (iii) fiscal distribution defined as social benefit expenditures as a proportion of GDP. The independent variables include: trade openness, outbound investment, financial openness, left party balance, electoral turnout, union density, wage-setting institutions, and log absolute GDP.

20. For further discussion of globalization and its effects on inequality see Williamson 
it possible to identify the sources of globalization and to associate globalization with economic policy measures to bring about desirable changes in national and international policies. In a regression analysis Heshmati investigates the relationship between income inequality, poverty and globalization. Results show that the globalization index explains only 7-II percent of the variations in income inequality, and 9 percent of poverty among the countries. By decomposing the aggregate globalization index into four components, results show that personal contacts and technology transfers reduce income inequality, while economic integration increases income inequality. Political engagement is found to have no significant effects on income inequality. The economic globalization component increases poverty, while personal contact reduces poverty. When controlling for regional heterogeneity, Heshmati finds that the regional variable plays an important role in explaining the variation in income inequality and poverty, thereby making the globalization coefficient insignificant.

\section{Summary of Factors Affecting World Income Distribution}

The non-uniform increase in wage inequality, the technical change biased against unskilled workers and the government's redistributive policies have resulted in the heterogeneous development of inequality among industrialized countries. In addition to the geographic factors, institutional structure and democracy play a role in the economic development and inequality of countries. Between-country inequality dominates the within-country component. The later can be more easily affected through policy interventions. Growth is found to increase income inequality. However, several studies conclude that the benefits of growth exceed the disadvantages to the poor. More evidence based on better data is needed to make inferences on growth and within-country distributional changes. Further studies are also needed to investigate the channels through which globalization affects world income inequality. Finally, the multidimensional links and direction of the causal relationships between the determinant factors (other than inequality growth and openness) have been neglected in the previous research.

\section{REDISTRIBUTION OF WORLD INCOME}

In this review a number of ways to construct world indices of income distribution and measure global income inequality reflecting both between- and withincountry inequalities have been presented. Few studies compare the individuals' income distribution of the world. A combined micro and macro approach is often used where mean per capita income complemented with some measures of income dispersion, or income shares from household surveys and demographic information is the standard data requirement to construct the world income distribution. Economic growth, population growth, life expectancy, and changes in the structure of income inequality are the most important factors determining the evolution of world income distribution. Empirical results show that world inequality measured as the Gini coefficient increased somewhat and poverty measured as headcount index (the share of the population whose income is below the poverty line) decreased. In sum, inequality within individual countries is not increasing but inequality between countries and regions is increasing as is the concentration of poverty in some regions. Given the skewed world income distribution and its development, the rest of this section reviews engaging and creative studies on how to bring about necessary changes to world income distribution in a desirable way. This section serves also as a summary of the review.

The issue of why we measure inequality is analyzed by Kaplow (2002). From the public finance perspective the problem of global redistribution has the same structure as the problem an individual country faces, namely the trade-off of efficiency costs of a progressive tax-transfer system against a more equal distribution of the welfare it achieves. World redistribution (cross-border transfers) is small relative to world inequality. Kopczuk, Slemrod and Yitzhaki (2002) investigate whether these minimal transfers are optimal, what the optimal transfers are, and consider the hypothetical case of an optimal linear world income tax that maximizes a border-neutral social welfare function. Using data from II8 countries a drastic reduction in world consumption inequality, a dropping of the Gini coefficient from 0.69 to 0.25 is obtained. However, decentralized within-country redistribution has little impact on overall world inequality. The actual foreign aid transfers from the US and other industrialized countries to the poor countries is a reflection of either placing a much lower value on the welfare of citizens of the poorest countries or else expecting that a very significant fraction of cross-border transfers is wasted.

The relative stability of income inequality within countries over time and the significant variability among countries is determined by political factors (civil liberties and schooling) and the way the capital market functions (financial depth and distribution of land), respectively (Li, Squire and Zou 1998). From the previous discussion of international and the intra-national inequality we can conclude that inequality is determined by factors that change slowly within countries but are quite different across countries. An optimal combination of cross-boarder transfers and within-country redistributive policies may simultaneously reduce substantially both within- and between-country inequalities.

Cornia and Court (200I) in a policy brief using the WIID database, covering the second wave of globalization, report changes in within-country income inequality and discuss the links between poverty, inequality and growth. The 
analysis highlights five main issues. First, inequality has risen since the early to mid-1980s. Second, what are traditionally seen as the most common factors causing inequality such as land concentration, urban bias and inequality in education are not responsible for worsening the situation. The new causes identified are the liberal economic policy regimes and the way in which economic reform policies have been carried out. Land reform, expanding education and active regional policy are recommended as measures to reduce inequality among areas, genders and regions. Third, the persistence of inequality at high levels makes poverty reduction difficult. There is a negative relationship between inequality and the poverty alleviation elasticity of growth (see also Cornia and Kiiski 200I). Fourth, a high level of inequality can depress the rate of growth, affect the stability of the global economy and have undesirable political and social impacts putting the market and globalization model at risk of a political backlash (see also Birdsall 1998). Fifth, developments in Canada and Taiwan show that low inequality can be maintained at fast growth.

Economic growth has often been given priority as an anti-poverty measure, but the negative link between growth and inequality has often been ignored by policymakers. Rising inequality threatens growth and poverty reduction targets calling for more distributionally favorable pro-growth policies. Policies offsetting the affect on inequality of new causes is designed and incorporated in a revised development approach called 'the Post-Washington Consensus' (Stiglitz 1998). These policies include measures to offset the impacts of new technologies and trade, macroeconomic stability, careful financial liberalization and regulation, equitable labor market policies, and innovative tax and transfer policies. Stiglitz concludes that the international community should consider distribution issues in advising on policy, avoid distributive distortions, try to reduce output volatility and increase external budgetary support.

Caminada and Goudswaard (200I) study the association between international trends in income inequality and social policy. They investigate whether changes in the overall distribution of income in OECD countries during the last two decades can be attributed to social policy measures. For most countries they find a possible relationship between changing welfare policies and changing income inequality, especially in the UK and the Netherlands. Fundamental social security reforms have made the income distribution less equal. Social transfers varied enormously across 15 EU countries in 1994. Heady, Mitrakos and Tsakloglou (200I) analyze the comparative effects of these transfers on inequality using the European Community Household Panel data (ECHP). The results show increasing distributional impacts of these transfers and the share of GDP spent on them (high in Denmark and the Netherlands and low in Greece and Portugal). However, the extent of means testing (high in the UK), the distribu- tion of different funds and the degree of targeting for each transfer also affects their impacts.

Locations in combination with immobility of factors are important for the incidence of poverty and justify regional targeting to reduce poverty. As an example Park, Wang and $\mathrm{Wu}(2002)$ evaluate the effectiveness of regional targeting in China's large-scale rural poverty alleviation investment program that began in I986 using a panel of all counties in China for the period 198I-1995. A number of targeting gaps and targeting error measures describing weighted mistargeting are defined. The evidence suggests that political constraints are likely to undermine regional targeting programs at the county level or higher. Targeting townships is the preferred level of targeting. There exist tradeoffs between targeting and other social objectives causing the deviation of optimal targets from the perfect ones.

In view of the above and from a public finance perspective global redistribution has the same structure as that of an individual country. World redistribution in the form of cross-border transfers is very small and not optimal relative to world inequality. Within-country redistribution has little impact on global inequality. Political and capital market factors determine the stability, changes and levels of inequality across countries. Land reform, expanding education and active regional policies are found to be effective economic reform policy measures to reduce inequality. On a smaller regional scale such as the EU, social security reforms show evidence of the positive impacts of taxes and targeting transfers on the distribution of income and inequality within and between the EU member countries. Political constraints and the level of targeting are important to the success of the regional targeting programs to reduce poverty.

In the analysis of factors causing inequality, it would be useful to broadly differentiate between factors affecting each of the within- and between-country components of inequality while also allowing for their overlapping factors. In the case of developing countries, the emphasis should be placed on the systematic discussion of important factors such as colonialism, institutions and governance, international trade, international debt, defense spending, infrastructure for economic development, structural adjustment programs and international aid. This will allow for the emergence of heterogeneous perspectives on the problem of inequality and the availability of resources and measures to reduce inequality. 


\section{REFERENCES}

Acemoglu, D. 2002. "Cross-Country Inequality Trends." NBER Working Paper No. 8832. Cambridge, MA: NBER.

Acemoglu, D., S. Johnson, and J.A. Robinson. 2002. "Reversal of Fortune: Geography and Institutions in the Making of the Modern World Income Distribution." Quarterly Journal of Economics II7(4): I23I-I294.

Acemoglu, D., and J.A. Robinson. 2000. "Why Did the West Extend the Franchise? Democracy, Inequality, and Growth in Historical Perspective." Quarterly Journal of Economics II5: II67-II99.

Acemoglu, D., and J. Ventura. 2002. "The World Income Distribution." Quarterly Journal of Economics $\operatorname{II} 7(2)$ : 659-694.

Anand, S. 1997. "The Measurement of Income Inequality." pp. 8I-105 in Measurement of Inequality and Poverty, edited by S. Subramanian. New Delhi and New York: Oxford University Press.

Atkinson, A.B. 1997. "Bringing Income Distribution in From the Cold." The Economic Journal 107: 297-321.

- I999. "Is Rising Inequality Inevitable? A Critique of the Transatlantic Consensus." The United Nations University, WIDER Annual Lectures 3. Helsinki: UNU/WIDER.

-2000. "Increased Income Inequality in OECD Countries and the Redistributive Impact of the Government Budget." WIDER Working Paper No. 202. Helsinki: UNU/WIDER.

Atkinson, A.B., and A. Brandolini. 200I. "Promise and Pitfalls in the Use of 'Secondary' Data-Sets: Income Inequality in OECD Countries as a Case Study." Journal Economic Literature 39: 77I-799.

Babones, S. J. 2002. "Population and Sample Selection Effects in Measuring International Income Inequality." Journal of World-Systems Research 8(I): 7-28 http://jwsr.ucr.edu.

Babones, S. J., and J. H. Turner. 2003. "Global Inequality." Chap. 7 in Handbook of Social Problems: A Comparative International Perspective, edited by G. Ritzer. Thousand Oaks, CA: Sage Publications.

Barro, R.J. I99I. "Economic Growth in a Cross Section of Countries." Quarterly Journal of Economics 106: 406-443.

Barro, R.J., and X. Sala-i-Martin. I995. Economic Growth. New York: McGraw-Hill Inc.

Bata, M., and A.J. Bergesen. 2002a. "Global Inequality: An Introduction." Journal of World-Systems Research 8(I): 2-6 http://jwsr.ucr.edu. .2002b. "Global Inequality: An Introduction." Journal of World-Systems Research 8(2): I46-I48 http://jwsr.ucr.edu.

Benabou, R. 1996. "Inequality and Growth." In NBER Macroeconomics Annual, edited by B.S. Bernanke and J. Rotemberg. Cambridge, MA: MIT Press.

Bergesen, A.J., and M. Bata. 2002. "Global and National Inequality: Are They Connected?" Journal of World-Systems Research 8(I): I29-I44 http://jwsr.ucr.edu.
Berry, A., F. Bourguignon, and C. Morrisson. 1983. "Changes in the World Distribution of Income Between 1950 and 1977." The Economic Journal 93(370): $33 \mathrm{I}-350$.

Birdsall, N. 1998. "Inequality and Global Coordination, Why Inequality Matters: The Developing and Transition Economies." Mimeo. Washington, D.C.: Carnegie Endowment for International Peace.

Bornschier, V. 2002. "Changing Income Inequality in the Second Half of the $20^{\text {th }}$ Century: Preliminary Findings and Propositions for Explanations." Journal of World-Systems Research 8(I): 99-I27 http://jwsr.ucr.edu.

Bourguignon, F., and C. Morrisson. 1999. "The Size Distribution of Income among the World Citizens." Mimeo. DELTA, École Normale Suérieure: Paris. - 2002. "Inequality among World Citizens: 1820-1992." American Economic Review 92(4): 727-747.

Bowles, S., and H. Gintis. 2002. "The Inheritance of Inequality." Journal of Economic Perspectives 6(3): 3-30.

Cameron, L.A. 2000. "Poverty and Inequality in Java: Examining the Impact of the Changing Age, Educational and Industrial Structure." Journal of Development Economics 62: 149-180.

Caminada, K., and K. Goudswaard. 200I. "International Trends in Income Inequality and Social Policy." International Tax and Public Finance 8(4): 395-4I5.

Capeau, B., and A. Decoster. 2003. "The Rise or Fall of World Inequality: Big Issue or Apparent Controversy?" Unpublished manuscript.

Chen S., G. Datt, and M. Ravallion. I994. "Is Poverty Increasing in the Developing World." Review of Income and Wealth 40(2):359-376.

Commander, A., A Tolstopiateniko, and R. Yemtsov. 1999. "Channels of Redistribution: Inequality and Poverty in the Russian Transition." Economics of Transition 7(2): 4II-447.

Cornia, G.A. I999. "Liberalization, Globalization and Income Distribution." WIDER Working Paper No. 157. Helsinki: UNU/WIDER.

Cornia, G.A., and J. Court. 200I. "Inequality, Growth and Poverty in the Era of Liberalization and Globalization." Policy Brief No. 4. Helsinki: UNU/WIDER.

Cornia, G.A., and S. Kiiski. 20or. "Trends in Income Distribution in the Post WWII Period: Evidence and Interpretation." WIDER Discussion Paper 200I/89. Helsinki: UNU/WIDER.

Cowell, F.A. 2000. "Measurement of Inequality." Pp. 87-166 in Handbook of Income Distribution. Volume I, edited by A.B. Atkinson and F. Bourguignon. Amsterdam: Elvesier.

Cowell, F.A., F.H.G. Ferreira, and J.A. Lichtfield. I998. "Income Distribution in Brazil 198I-I990: Parametric and Non-Parametric Approaches." Journal of Income Distribution 8(I): 63-76.

De Gregorio, J., and J-W. Lee. 2002. "Education and Income Inequality: New Evidence from Cross-Country Data." Review of Income and Wealth 48(3): 395$4 \mathrm{I} 6$. 
Deininger, K., and L. Squire 1996. "A New Data Set Measuring Income Inequality." World Bank Economic Review Io(3): 565-59I.

Devroye, D., and R. Freeman. 200I. "Does Inequality in Skills Explain Inequality of Earnings Across Advanced Countries?” NBER Working Paper No. 8140. Cambridge, MA: NBER.

Dikhanov, Y., and M. Ward. 2002. "Evolution on the Global Distribution of Income in 1970-99." Paper presented at the International Workshop on Income Distribution and Welfare, Bocconi Univeristy, Milan, Italy, May 30 to June 2.

Dollar D., and P. Collier. 200I. Globalization, Growth and Poverty: Building an Inclusive World Economy. New York: Oxford University Press.

Dollar, D., and A. Kraay. 20or. "Trade, Growth, and Poverty." World Bank, Development Research Group.

Eicher, T.S., and C. Garcia-Penalosa. 20or "Inequality and Growth: The Dual Role of Human Capital in Development." Journal of Development Economics 66: I73-197.

Fan, C.S., J. Overland, and M. Spagat. I999. "Human Capital, Growth and Inequality in Russia." Journal of Comparative Economics 27(4): 6I8-643.

Firebaugh, G. 1999. "Empirics of World Income Inequality." American Journal of Sociology 104(6): 1597-1630.

- 2000a. "The Trend in Between-Nation Income Inequality." American Review of Sociology 26: 323-339.

- 200ob. "Observed Trends in Between-Nation Income Inequality and Two Conjectures." American Journal of Sociology I06(I): 215-22I.

Firebaugh, G., and B. Goesling 2004. "Accounting for the Recent Decline in Global Income Inequality." American Journal of Sociology IIO(2): 283-3I2.

Fischer, R.D. 200I. "The Evolution of Inequality after Trade Liberalization." Journal of Development Economics 66:555-579.

Gottschalk, P. 1997. "Inequality, Income Growth, and Mobility: The Basic Facts.” Journal of Economic Perspectives II (2): 2I-40.

Gottschalk, P., and T.M Smeeding. 1997. "Cross-National Comparisons of Earnings and Income Inequality." Journal of Economic Literature 35:633-687.

. 2000. "Empirical Evidence on Income Inequality in Industrialized Countries." PP. 26I-308 in Handbook of Income Distribution. Volume I, edited by A.B. Atkinson and F. Bourguignon. Amsterdam: Elsevier.

Gradstein, M., and B. Milanovic. 2002. "Does Liberte=Egalite? A Survey of the Empirical Links between Democracy and Inequality With Some Evidence on the Transition Economies." World Bank Policy Research Working Paper $2002 / 2875$.

Gustafsson, B., and L. Shi, 2002. "Income Inequality Within and Across Counties in Rural China I988 and 1995." Journal of Development Economics 69(I): I79-204.

Heady, C., T. Mitrakos, and P. Tsakloglou. 200I. "The Distributional Impact of Social Transfers in the European Union: Evidence from the ECHP." Fiscal Studies 22(4):547-565.
Heshmati, A. 2003. "Measurement of a Multidimensional Index of Globalization and Its Impact on Income Inequality." WIDER Discussion Paper 2003/69. Helsinki: UNU/WIDER.

2004a. "Inequalities and Their Measurement." IZA Discussion Paper 2004/I219. Boon, Germany: IZA.

2004b. "A Review of Decomposition of Income Inequality." IZA

Discussion Paper 2004/I22I. Boon, Germany: IZA.

- 2004c. "Growth, Inequality and Poverty Relationships." IZA Discussion Paper 2004/I338. Boon, Germany: IZA.

. 2004d. "Continental and Sub-Continental Income Inequality." IZA

Discussion Paper 2004/I27I. Boon, Germany: IZA.

. 2004e. "Regional Income Inequality in Selected Large Countries." IZA

Discussion Paper 2004/1307. Boon, Germany: IZA.

.2004f. "Data Issues and Databases used in Analysis of Growth: Poverty and Economic Inequality." IZA Discussion Paper 2004/I263. Bonn, Germany: IZA.

. 2004g. "The Relationship between Income Inequality, Poverty an Globalization." IZA Discussion Paper 2004/I277. Boon, Germany: IZA.

Hurrell, A. 200I. "Global Inequality and International Institutions." Metaphilosophy $32(\mathrm{I} / 2) \div 34-57$.

Iacoviello, M. I998. "Inequality Dynamics: Evidence from Some European Countries.” Working Paper No. I9I. Maxwell School of Citizenship and Public Affairs, Syracuse University.

Islam, N. 1995. "Growth Empirics: A Panel Data Approach." Quarterly Journal of Economics IIO: II27-II70.

Jones, C.I. 1997. "On the Evolution of the World Income Distribution." Journal of Economic Perspectives II (3): I9-36.

Kaplow, L. 2002. "Why Measure Inequality?” NBER Working Paper No. 9342. Cambridge. MA: NBER.

Kopezuk, W., J. Slemrod, and S. Yitzhaki. 2002. "Why World Distribution Fails." NBER Working Paper No. 9I86. Cambridge. MA: NBER.

Korzeniewicz, R.P., and T.P. Moran. 2000. "Measuring World Income Inequalities." American Journal of Sociology I06(I): 209-2I4.

Li, H., L. Squire, and H. Zou. 1998. "Explaining International and Intertemporal Variations in Income Inequality." The Economic Journal 108(466): 26-43.

Liebbrandt, M., C. Woolard, and I. Woolard. 2000. "The Contribution of Income Components to Income Inequality in the Rural Former Homelands of South Africa: A Decomposable Gini Analysis." Journal of African Economies 9(I): 79-99.

Lindert, P.H., and J.G. Williamson. 200I. "Does Globalization Make the World More Unequal?” NBER Working Paper No. 8228. Cambridge, MA: NBER.

Londono, J.L., and M. Szekely. 2000. "Persistent Poverty and Excess Inequality: Latin America, I970-I995." Journal of Applied Economics 3(I): 93-I34. 
Maddison, A. 200I. "The World Economy: A Millennial Perspective." Development Centre Studies. Paris: OECD.

Mahler, V.A. 200I. "Economic Globalization, Domestic Politics and Income Inequality in the Developed Countries: A Cross-National Analysis."

Luxembourg Income Study Working Paper 273. Luxembourg; Syracuse University, NY.

Mankiw, N.G., D. Romer, and D.H. Weil. 1992. "A Contribution to the Empirics of Economics Growth." Quarterly Journal of Economics 107: 407-438.

Milanovic, B. 200I. "World Income Inequality in the Second Half of the $20^{\text {th }}$ Century." World Bank, Development Research Group.

.2002a. "True World Income Distribution, I988 and 1993: First

Calculation Based on Household Surveys Alone." The Economic Journal II $2(476): 5 I-92$.

- 2002b, "Can We Discern the Effect of Globalization on Income

Distribution? Evidence from Household Budget Surveys." World Bank Policy Research Working Paper 2002/2876.

Milanovic, B., and S. Yitzhaki. 200I. "Decomposing World Income Distribution: Does the World Have a Middle Class?" World Bank Policy Research Working Paper 2001/2562.

O’Rourke, K.H. 200I. "Globalization and Inequality: Historical Trends." NBER Working Paper No. 8339. Cambridge, MA: NBER.

O'Rourke, K.H., and J.G. Williamson. 2000. Globalization and History: The Evolution of a Nineteenth-Century Atlantic Economy. Cambridge, MA: MIT Press.

Park, D. 200I. "Recent Trends in the Global Distribution of Income." Journal of Policy Modeling 23: 497-50I.

Park, A., S. Wang, and G. Wu. 2002. "Regional Poverty Targeting in China," Journal of Public Economics 86: I23-153.

Pyatt, G. 1976. "On the Interpretation and Disaggregation of Gini Coefficient." The Economic Journal 86(342): 243-255.

Quah, D. 1996. "Empirics for Economic Growth and Convergence." European Economic Review 40: I353-I375.

- I999. "Some Dynamics of Global Inequality and Growth." Mimeo. London School of Economics.

- 200I. "Some Simple Arithmetic on How Income Inequality and Economic Growth Matter." Paper presented at the WIDER conference on Growth and Poverty, May I5-26, Helsinki, Finland. - 2002. "One Third of the World's Growth and Inequality." CEPR Discussion Paper No. 3316. London, England: CEPR.

Ravallion, M. 200I. "Growth, Inequality and Poverty: Looking Beyond Averages." World Development 29(II): I803-I8I5. - 2003. "Inequality Convergence." Economics Letters 80:35I-356.

Ravallion, M., and S. Chen. 1999. "When Economic Reform is Faster than Statistical Reform: Measuring and Explaining Income Inequality in Rural China." Oxford Bulletin of Economics and Statistics 6r: 33-56.
The World Distribution of Income and Income Inequality

Ravallion, M., and G. Datt. 200o. "When Growth is Pro-Poor? Evidence from the Diverse Experience of Indian States." World Bank Policy Research Working Paper 2000/2263.

Ravallion, M., G. Datt, and D. van der Walle. I99. "Quantifying Absolute Poverty in the Developing World." Review of Income and Wealth 37(4): 345-36I.

Sala-i-Martin, X. 2002a. “The Disturbing 'Rise' of Global Income Inequality.” NBER Working Paper No. 8904. Cambridge, MA: NBER.

8933. Cambridge, MA: NBER.

Schultz, T.P. 1998. "Inequality in Distribution of Personal Income in the World: How it is Changing and Why." Journal of Population Economics II (3): 307-344 Seligson, M., and J. Passe-Smith., eds. 2003. Development and Underdevelopment: The Political Economy of Global Inequality. Boulder, CO: Lynne Reinner Publishers.

Solimano, A. 200I. "The Evolution of World Income Inequality: Assessing the Impact of Globalization." Unpublished manuscript, ECLAC, CEPAL - Serie Macroeconomica del desarrollo No. II, Santiago, Chile.

Stiglitz, J.E. 1998. "More Instruments and Broader Goals: Moving Towards the PostWashington Consensus." WIDER Annual Lecture 2. Helsinki: UNU/WIDER.

Subramanian, S., ed. 1997. Measurement of Inequality and Poverty. New Delhi and New York: Oxford University Press.

Wade, R.H. 20ora. "Global Inequality: Winners and Losers." The Economist, April 28

- 200Ib. "Is Globalization Making World Income Distribution More Equal?” Working Paper Series or. London: LSE Development Studies Institute.

Williamson, J.G. 1996. "Globalization and Inequality Then and Now: The Late $19^{\text {th }}$ and $20^{\text {th }}$ Centuries." NBER Working Paper No. 5491. Cambridge, MA: NBER.

Wood, A., and C. Ridao-Cano. I999. "Skill, Trade, and International Inequality." Oxford Economic Papers 5I: 89-II9. 


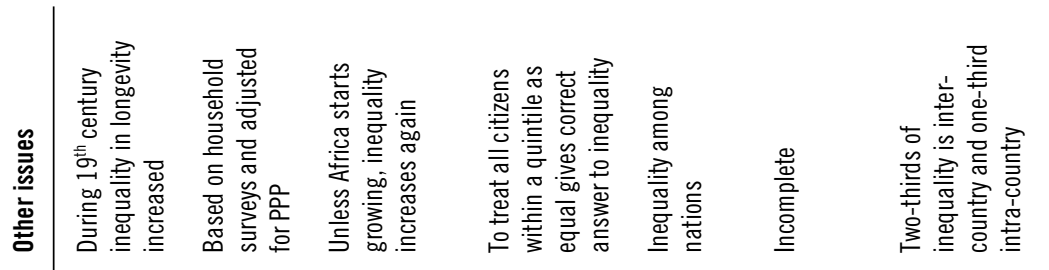

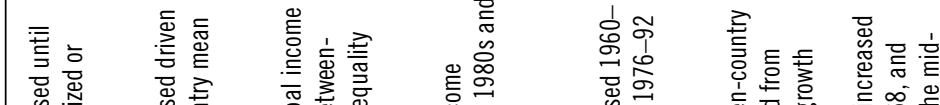

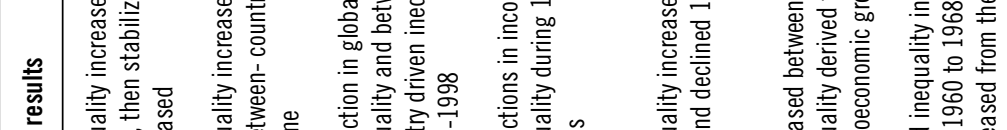

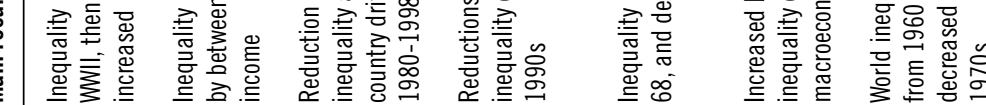

\section{竞言}

응호를

흥 = 홓

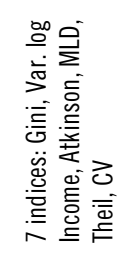

这高

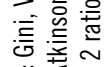

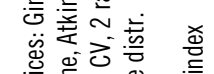

1-

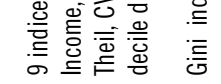

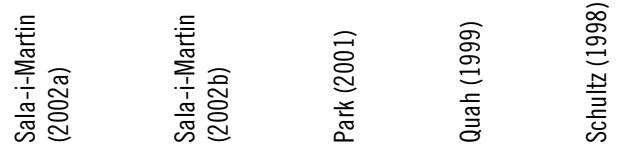

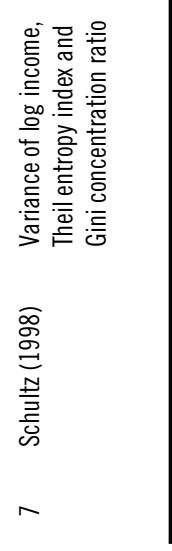

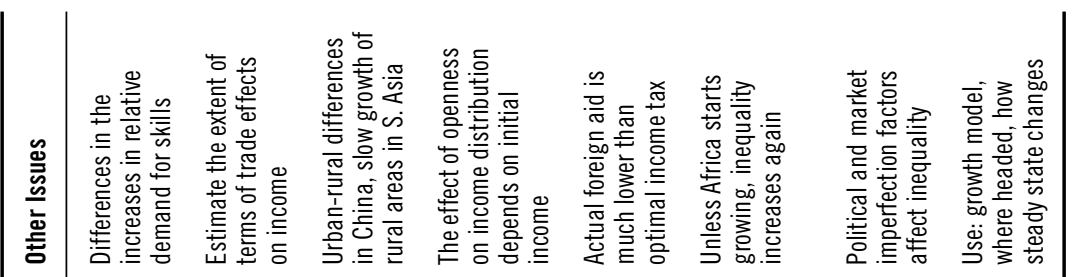

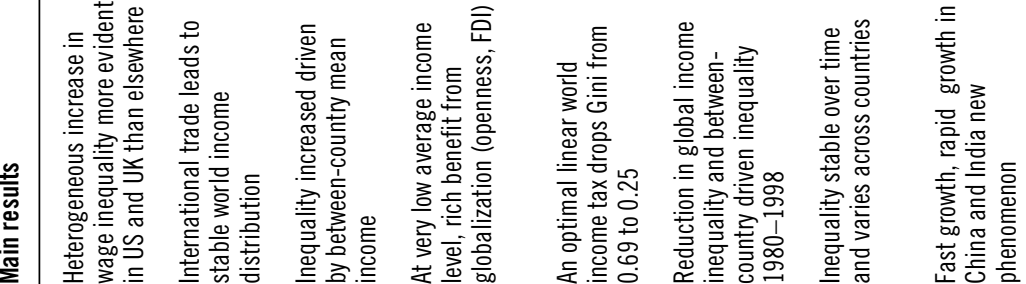

递

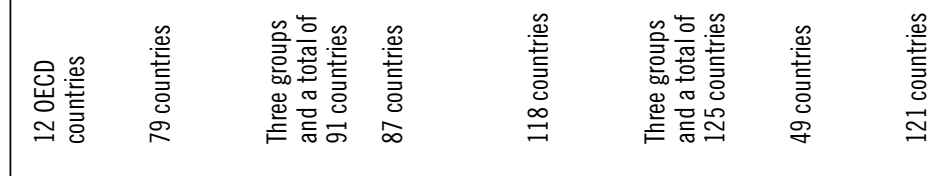

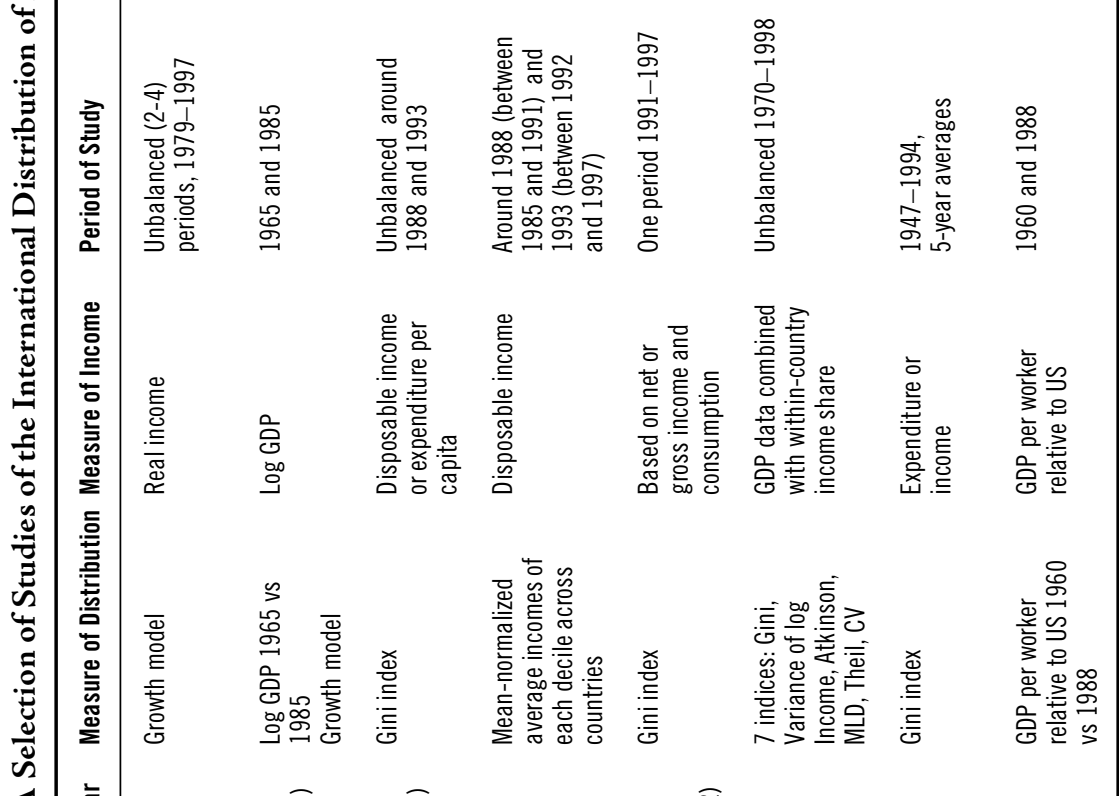

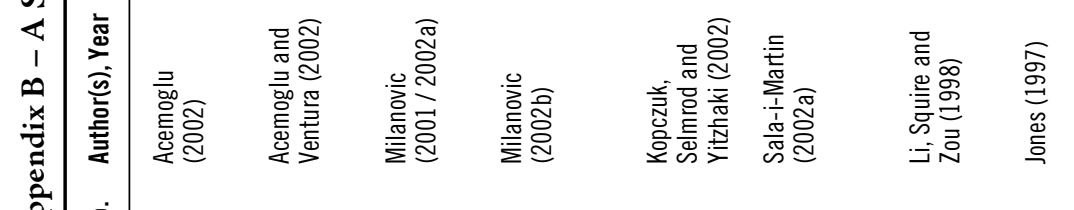




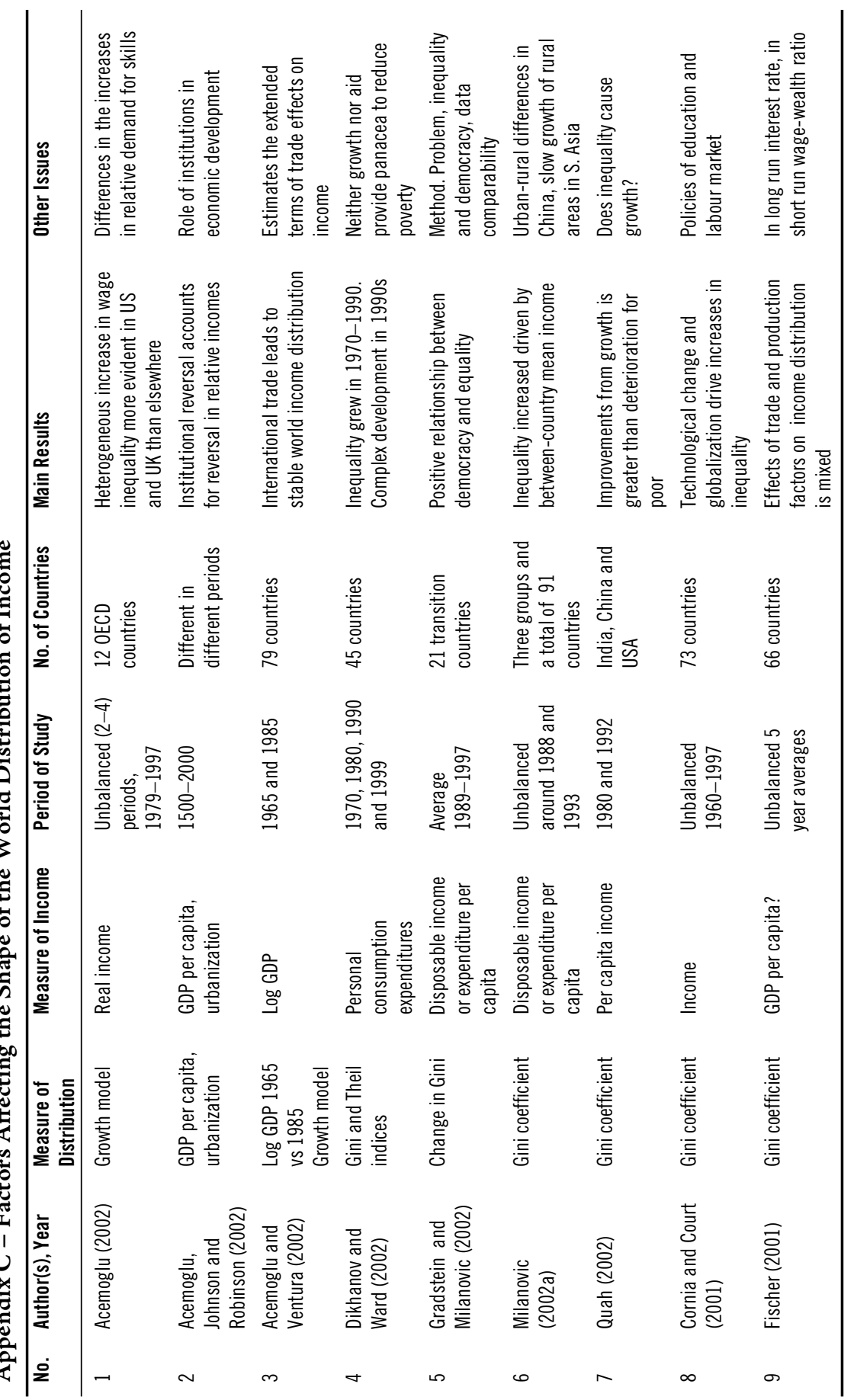

The World Distribution of Income and Income Inequality

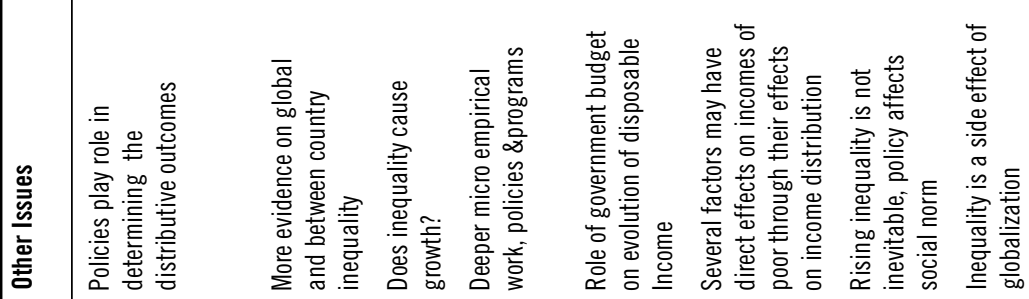

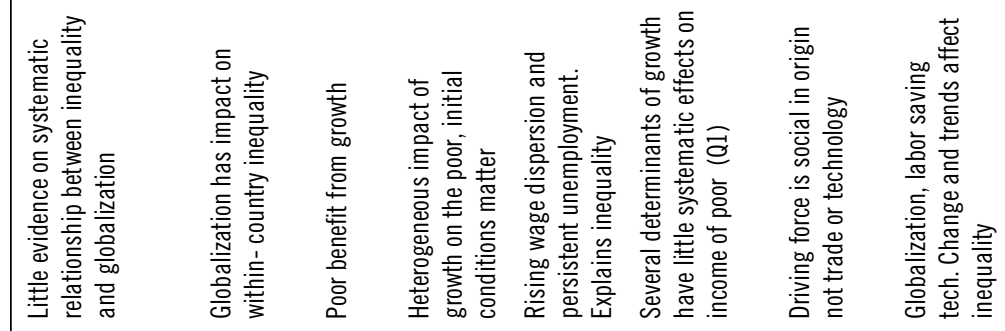

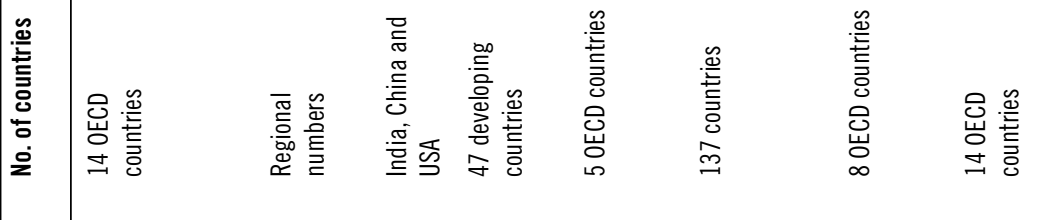

旁 I

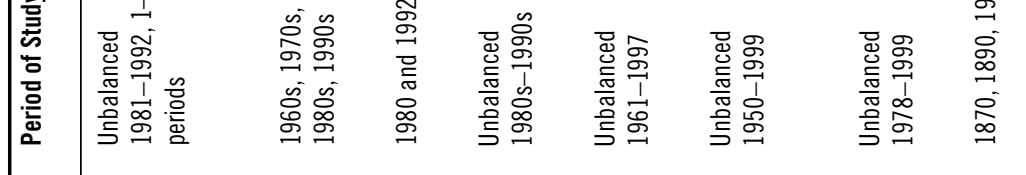

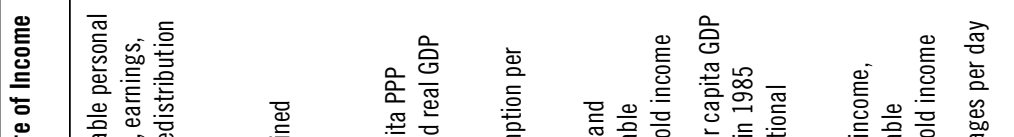

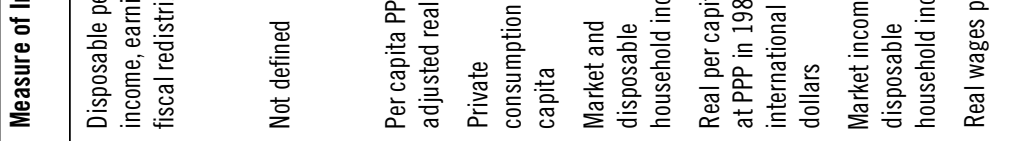

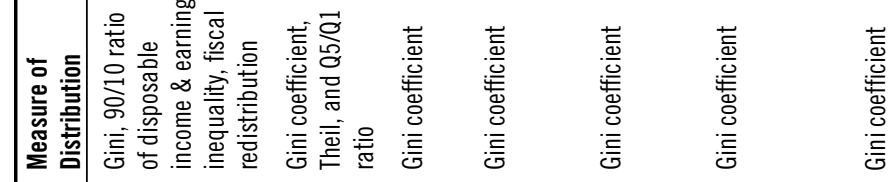

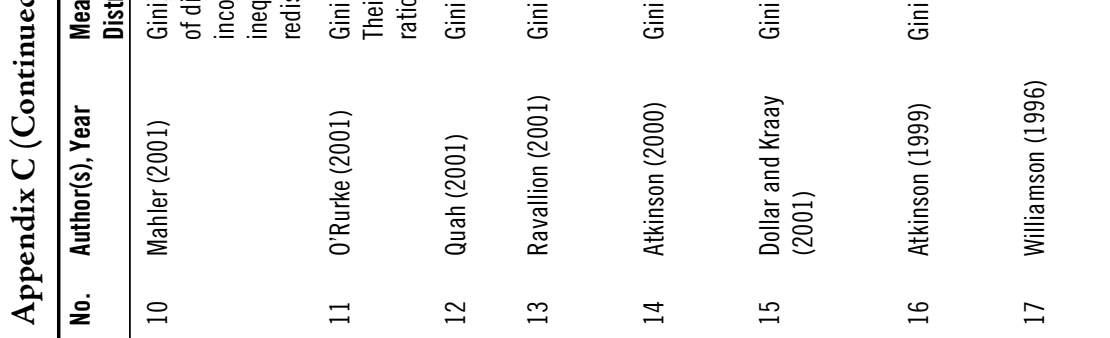

